\title{
What is a Fair Amount of Executive Compensation? Outrage Potential of Two Key Stakeholder Groups
}

\author{
Markus C. Arnold \\ Robert Grasser ${ }^{\mathrm{b}}$
}

November 2017

\begin{abstract}
${ }^{\text {a }}$ University of Bern, Institute for Accounting, Engehaldenstrasse 4, 3012 Bern, Switzerland. E-mail: markus.arnold@iuc.unibe.ch

${ }^{\mathrm{b}}$ Corresponding author. University of South Carolina, Darla Moore School of Business, 1014 Greene St, Columbia, SC 29208, U.S.A. Tel.: +1 8037774981.

E-mail: robert.grasser@moore.sc.edu
\end{abstract}

\section{Acknowledgements}

The authors greatly appreciate the helpful comments and suggestions from Steven Young (editor), an anonymous reviewer, as well as from Martin Artz, Olaf Bock, Jürgen Ernstberger, Robert Gillenkirch, Barbara Weißenberger and participants of the 2014 Annual Conference of Management Accounting Research. We also thank the GESIS (Leibniz Institute for the Social Sciences), the WiSo Research Laboratory of the University of Hamburg, the Society of Investment Professionals in Germany (DVFA). Finally, we want to thank Ralf Frank and Michael Kolb for their support in conducting the survey studies. 


\title{
What is a Fair Amount of Executive Compensation? Outrage Potential of Two Key Stakeholder Groups
}

\begin{abstract}
The public discussion of executive compensation often centers on "fair" and "unfair" amounts and the public outrage over compensation that is deemed too high. The academic literature states that such outrage can lead to outrage costs, pressuring firms to adjust the level of compensation. However, it is unclear what a "fair" compensation is for various stakeholders and how their fairness concerns relate to outrage constraints. Based on surveys among two key stakeholder groups (representative eligible voters and investment professionals), we provide evidence that fairness is an important criterion for both groups but that opinions on how large a fair compensation amount should be are widely dispersed. Moreover, personality traits systematically influence fairness opinions through self-serving interpretations of distributive justice and personal risk attitudes, indicating that a "fair" amount of executive compensation may strongly depend on the involved stakeholders. Investigating thresholds for outrage, i.e., amounts above which compensation is judged "unfairly" high, we show that even though investment professionals care for fairness as well, "capital market outrage" might not equate to "public outrage". Our paper contributes to the literature on outrage constraints by linking individual fairness concerns to outrage potential and has implications for transparency of executive compensation and research on shareholder activism.
\end{abstract}

Keywords: Executive compensation, distributive justice, fairness, outrage constraints, public outrage. 


\section{INTRODUCTION}

Discussions in the media and politics often claim that the amount of executive compensation should be "fair" and that current pay practices are not. Consistent with the increased public criticism peaking during the financial crisis (e.g., Page and Jacobs, 2009), the media has covered stories of exceptionally high compensation in general and compensation scandals in particular (Core et al., 2008). The question of "sufficient" amounts of executive compensation has also been raised in research (e.g., Abowd and Kaplan, 1999; Edmans and Gabaix, 2009). Additionally, institutional investors seem concerned about the level of executive compensation (Brandes et al., 2008; McCahery and Sautner, 2012). Taken together, this evidence points at increased public pressure from stakeholders in general and investors in particular to limit the amount of executive compensation. Our study investigates fairness concerns about executive compensation of two stakeholder groups-eligible voters and investment professionals - and the role of such concerns for "outrage constraints".

As illustrated by the following quotes, the perceived fairness of executive compensation seems to play a major role in outrage about executive compensation:

Why bonuses feel so unfair - Greed. Inequality. Envy. There's no mystery as to why bankers have overtaken lawyers in the unpopularity stakes. At the heart of the public's resentment of the bonus culture is the concept of fairness. - The Telegraph (07 Feb 2012)

Over the last few years, the perceived divergence between UK economic and corporate performance and executive pay levels appeared unjustified and fuelled the public and political outcry over so called 'payments for failure'. -EY, Into the Light (2014)

Such public outrage about "unfair" executive compensation is often referred to as an "outrage cost" or "outrage constraint" (Bruce et al., 2005; Conyon, 2006). Specifically, the (potential) outrage among the public, employees, or shareholders is suggested to limit the amount of executive compensation, as it may hurt executives' reputation or lead to decreased shareholder support for executive proposals at the shareholder meeting (Core et al., 2008; Hooghiemstra et al., 2015). Some authors even perceive outrage costs as one of the most effective means to limit executives' power over their own compensation (Bebchuk and Fried 
2004). Likewise, increased public interest in disclosure and the disciplining force of outrage also seem to be the impetus for new regulations about increased transparency of executive compensation and say-on-pay mechanisms like, for example, the Dodd-Frank Act of 2010, sections 951 and 953, and UK's Directors' Remuneration Report Regulations of 2002 (Conyon et al., 2013). Increased transparency may help regulate executive compensation if firms anticipate outrage among informed stakeholders for high compensation amounts and adjust their executive compensation accordingly (Bebchuk and Fried, 2003; Conyon, 2014).

Prior research on the outrage constraint has provided some evidence that the level and structure of executive compensation responds to (nonbinding) shareholder votes (e.g., Alissa, 2015; Ferri and Sandino, 2009) and negative press coverage (Johnson et al., 1997; Kuhnen and Niessen, 2012). Thus, potential stakeholder outrage seems to matter to firms. Little is known, however, about what constitutes the potential for "public outrage", how fairness preferences of stakeholders could enter into executive compensation and whether fairness preferences about executive compensation in the broader "public" opinion differ from "market" views on executive compensation. Prior research often used either negative press coverage (e.g., Kuhnen and Niessen, 2012) or levels of shareholder voting dissent (e.g., Ferri and Maber, 2013) to proxy for outrage ex post. In contrast, this paper is the first to attempt to measure outrage potential by investigating opinions on "fair" and "unfair" executive compensation of two key stakeholder groups, eligible voters, who represent the public perspective, and investment professionals, who represent the market perspective.

As we will explain in more detail below, the question of what constitutes a fair amount of executive compensation closely relates to the concept of distributive justice (Adams, 1965; Hoffman and Spitzer, 1985). However, even though most people claim to care about fairness, individual definitions of fairness are usually ambiguous and subjective (Cappelen et al., 2005; Konow, 2000). This could imply that opinions among stakeholders about "fair" executive compensation amounts may be widely dispersed. If this is the case, it may be difficult to find 
a single fair amount of executive compensation for each firm that most stakeholders would agree with. Moreover, based on theory from social psychology, we predict that opinions on the fair amount of executive compensation are not unsystematically dispersed but systematically biased according to stakeholders' personality traits. This would additionally complicate the determination of a "fair" compensation amount as it would not only depend on the firm and its characteristics but also on stakeholders' and shareholders' personality traits.

Specifically, we examine two paths for personality traits to influence perceptions of fair compensation amounts. First, individuals could exhibit egocentric fairness biases (Babcock and Loewenstein, 1997), i.e., their opinion on fair compensation is motivated by self-serving interpretations of fairness and therefore depends on their perceived similarity with executives. Second, based on social projection theory (Krueger and Clement, 1997; Ross et al., 1977; Taft, 1955), individuals' own attitudes toward risk-affected variable pay could carry over to their preferences for executives' compensation structure. As we also expect that fairness considerations include compensation for the risk associated with a more variable pay structure, personality traits could, again, bias opinions on "fair" amounts.

Because it may be difficult to determine a single "fair" executive compensation amount that could be used to avoid outrage costs, and therefore, could be traded off against other costs and benefits of executive compensation, we also examine a second way of how fairness preferences may enter into executive compensation. Specifically, we also investigate outrage thresholds. By outrage threshold, we mean an amount above which executive compensation is perceived as "unfairly" high. While such outrage thresholds are likely to be influenced by personality traits as well, they might be less demanding than a strict fairness criterion. That is, to avoid outrage, it might be sufficient that a large enough fraction of shareholders and stakeholders do not perceive the compensation as "unfairly" high. Thus, outrage costs may rather be related to the "unfairness" of executive compensation than to its "fairness".

We investigate our research question via two surveys among eligible voters and investment 
professionals in Germany. The German setting is particularly apt to analyze our question as it is characterized by a stakeholder culture, high employee representation, and an active role for the government in regulating executive compensation. Thus, executive compensation plays an important role for different stakeholder groups. In the first survey, we gather data from 671 representative eligible voters in the state of Hamburg as part of a bigger survey on political opinions and attitudes. Our data comprises opinions on both the fairness of executive compensation and the preferred structure of variable and fixed executive pay. We also gather data about personality traits of the survey participants. In the second survey, we collect data from 140 investment professionals, primarily located in Germany, about their opinions on fair executive compensation and preferred executive pay structures. We use these different groups for two main reasons: First, as prior research often assumes that investors are mainly interested in economic criteria and corporate governance of executive compensation (Core et al., 1999; David et al., 1998; Hartzell and Starks, 2003), we explore whether fairness perceptions and corresponding thresholds are relevant to investment professionals. Second, if investors exhibit fairness preferences related to executive compensation as well, potential differences and similarities between voters proxying "the public" and investment professionals proxying "market" opinions, may generate insights into the relation between outrage in the media and say-on-pay voting and other shareholder activism.

The results of our two surveys show that the majority of both groups exhibit fairness preferences related to executive compensation but that fairness opinions are widely dispersed in both groups. As predicted, opinions are also related to individuals' personality traits, suggesting that the emergence of outrage may depend on the personalities of the involved stakeholders. These results indicate that it seems difficult to find a single "fair" amount of executive compensation that satisfies all stakeholders. When examining outrage thresholds, we find that the actual CEO compensation amounts in all of the 30 largest exchange-listed German firms exceed the outrage thresholds of the majority of eligible voters. Yet, only half 
of these firms exceed the outrage thresholds of the majority of investment professionals. This result indicates potential differences in "public" outrage and outrage at the capital market. Finally, as transparency about executive compensation is an important prerequisite for outrage to become effective, we also analyze how well participants estimated the actual amounts of executive compensation. Our results show that most participants largely under- or overestimate executives' actual compensation. Thus, despite recent efforts to improve transparency about executive compensation, our surveys among German stakeholders cast some doubt about the effectiveness of these efforts in this country.

Our study makes several contributions to research and practice. First, we contribute to the literature on outrage costs by providing evidence that a large majority of both eligible voters and investment professionals exhibit fairness preferences related to the amount of executive compensation. We also add to prior research on say-on-pay voting dissent (Alissa, 2015; Ertimur et al., 2013; Ferri and Maber, 2013) and negative press coverage (Core et al., 2008; Kuhnen and Niessen, 2012). While these studies typically capture outrage ex post, we focus on outrage potential ex ante by studying executive compensation amounts that our participants perceive as "fair" or "unfair". Thus, we document fairness preferences as an important source for the emergence of outrage and identify compensation levels that may lead to outrage.

Second, our finding that fairness preferences are widely dispersed illustrates that a single fair amount of executive compensation that satisfies all stakeholders is unlikely to exist. Moreover, the fact that personality traits are associated with opinions on fair executive compensation implies that firms may benefit from considering which stakeholder groups may be interested in their executive compensation decisions. Firms may even have incentives to try to influence the composition of the shareholder base and the board.

Third, by comparing outrage thresholds of eligible voters and investment professionals we contribute to prior research on outrage costs. We find that executive compensation in some firms exceeds outrage thresholds of both the majority of voters and investment professionals 
whereas, for other firms, thresholds are only exceeded for the majority of voters. This result may help explain mixed findings on the effectiveness of media coverage as an outrage constraint for executive compensation (Core et al., 2008; Hooghiemstra et al., 2015; Kuhnen and Niessen, 2012). Specifically, the fact that investors have higher outrage thresholds, rather than being indifferent about the fairness of executive compensation, could help explain the weak relation between public outrage (as proxied by media coverage) and shareholder voting.

Finally, by analyzing estimates of actual executive compensation, we can help build a bridge between the notion of an outrage constraint and the public interest in disclosure. The observed gap between actual and estimated executive pay suggests that recent efforts to improve the transparency of executive compensation in Germany may not have succeeded yet. Hence, as transparency is needed to transform outrage potential into actual outrage and to become an effective constraint, transparency mechanisms may still need to be improved.

\section{BACKGROUND}

\section{(i) The Disclosure of Executive Compensation and the Notion of Fairness}

Early research on executive compensation focused predominantly on the relationship between pay and performance (Abowd, 1990; Jensen and Murphy, 1990). While at first this relationship was criticized as being too weak (e.g., Baker et al., 1988), concerns about pay levels also began to grow in the aftermath of strong increases in compensation during the 1990s and several compensation scandals that came to light (Abowd and Kaplan, 1999; Murphy, 1999). Subsequently, executive compensation has remained an ongoing concern in Europe and the US (Conyon et al., 2013; Murphy, 2012).

In an attempt to explain rising compensation levels, the managerial power approach suggests that executives shape their own compensation, resulting in rent extraction, inefficient incentives, and camouflage compensation (Bebchuk and Fried, 2003, 2004, 2005; Bertrand and Mullainathan, 2001). Calls for more transparency as a disciplining instrument have often 
been made (e.g., Bebchuk and Fried, 2005), and regulators have emphasized corporate governance and compensation disclosure in recent years (e.g., SEC, 2006; The Dodd-Frank Act, 2010). The proposed benefits of more transparency are based on the belief that the public opinion can influence the level and structure of compensation because outrage of different stakeholders is costly to managers, directors, and firms in the form of embarrassment, reputational harm, and declining shareholder support (Bebchuk and Fried, 2003). However, empirical evidence on the effectiveness of negative press coverage for this so-called outrage constraint is mixed. Johnson et al. (1997) find smaller pay increases in firms that have been singled out in the press, but Core et al. (2008) find only little evidence that firms lower their compensation. Kuhnen and Niessen (2012) find a change in the mix of compensation components but not in the overall amount.

Similar to research on public outrage, prior research on shareholders has also taken existing outrage as a starting point for the analysis. For example, Ferri and Maber (2013) proxy for outrage ex post with say-on-pay voting behavior. While characterizing $20 \%$ dissent as high, their data do not allow them to determine whether shareholders who dissent do so due to concerns about the fairness of pay levels or due to concerns about other aspects of the compensation package like a lack of pay-for-performance. Furthermore, voting dissent does not inform what pay levels could trigger dissent ex ante. Similarly, McCahery and Sautner (2012) study investors' concerns about pay levels, but do not distinguish between fairness and other motives like concerns about rent extraction. We aim to fill this void by investigating the role of fairness concerns as a possible driver of stakeholder outrage from an ex ante perspective. This is important for firms and researchers as policies that allow for more shareholder influence, like say-on-pay, become more pervasive (Conyon and Sadler, 2010). A better understanding of how pay levels affect the potential for outrage from different stakeholders may help firms avoid outrage costs. Second, analyzing investors' fairness concerns separately from their governance concerns can inform research on outrage 
constraints about an understudied motive in executive pay decisions. Finally, analyzing outrage potential of different stakeholders may add to understanding the relationship between public outrage and shareholder outrage.

To study stakeholders' opinions on fair executive compensation amounts, we draw on distributive justice theories (Konow, 2003). As in our setting, distributive justice relates to the relative positions of two (or more) parties to each other. Under this concept, "fair" executive compensation can include amounts that are both quite low or rather high. ${ }^{1}$ In the following, we argue that individual interpretations of distributive justice are associated with systematic variation in stakeholders' opinions on fair executive compensation. ${ }^{2}$

Recently, the concept of distributive justice also gained importance in executive compensation disclosure. Specifically, as of 2017, Section 953(b) of the Dodd-Frank Act requires disclosing median employee pay and its ratio to CEO pay, thereby opening up the possibility to relate executive compensation to estimated inputs of employees and executives. An experiment by Kelly and Seow (2016) suggests that distributive justice aspects of compensation disclosure can negatively affect participants' judgements of CEO pay fairness and perceived workplace climate but simultaneously increase the expected ability to attract and retain $\mathrm{CEO}$ talent.

\footnotetext{
${ }^{1}$ Distributive justice distinguishes between the equity and the equality principle. According to the equality principle, a distribution is fair when all individuals receive the same reward (Konow, 1996). The equity principle relates individuals' fair rewards to their personal inputs (Adams, 1965; Hoffman and Spitzer, 1985), so that higher rewards are perceived as fair when a person is perceived to provide higher inputs. Therefore, opinions on fair executive compensation can differ by how individuals value executive inputs.

${ }^{2}$ To provide evidence that distributive justice preferences may vary among participants, we conducted an additional survey among 406 eligible voters among the same population as our main survey. In this survey, we find that $90.38 \%$ agree with a statement in support of the equity principle: "It is fair that people who contribute more also earn more money". 9.62\% support the equality principle: "It is fair that all people earn the same amount of money, regardless of their contribution". This is consistent with O'Brien's (2011) findings for the UK. Additionally, participants, on average, perceive higher inputs of executives than of regular employees. In particular, we asked on a seven-point Likert scale whether, relative to regular employees, executives "carry more responsibility", their "actions and decisions have a greater influence on the success of the firm", they "make bigger personal sacrifices (e.g., leisure and family)", and "are exposed to more stress and personal pressure". The mean values are between 4.42 and 5.27, which is significantly larger than the midpoint of the scale and substantially larger than 1, which would reject the idea of larger executive contributions. Both results imply that individual interpretations of distributive justice could be diverse and that our survey population may generally view executive compensation that exceeds the compensation for average employees to be fair.
} 


\section{(ii) Institutional Background in Germany}

The institutional setting in Germany is particularly apt to study fairness concerns as a source of outrage costs for mainly three reasons. (1) Germany's corporate governance system is stakeholder-oriented rather than shareholder-oriented. (2) Germany's two-tier board system is characterized by so-called codetermination, i.e., the representation of employees in the supervisory board. (3) Government has traditionally been a large shareholder and actively regulates executive compensation.

While Anglo-Saxon countries have mainly adopted a shareholder value perspective (Denis and McConnell, 2003; Simnett et al., 2009), Germany has a stakeholder-oriented view (Fiss and Zajac, 2004). From this view, the corporation is supposed to consider the interests of multiple stakeholders, including shareholders, employees, creditors, and the government (Fauver and Fuerst, 2006; Schmidt and Tyrell, 1997), making potential outrage from multiple groups other than shareholders more relevant. In contrast to the one-tier board system in Anglo-Saxon countries in which executive board members manage the daily operations and non-executive board members supervise the executives, Germany has a two-tier system (du Plessis et al., 2012; Weimer and Pape, 1999). In this system, the management board ("Vorstand") develops strategy and runs the daily business, whereas the supervisory board ("Aufsichtsrat") monitors and advises the management board. The latter is also responsible for the appointment and removal of management board members and for overseeing their compensation (du Plessis et al., 2012; Larcker and Tayan, 2011).

The second important feature of German corporate governance is the concept of codetermination ("Mitbestimmung"). Firms with more than 2,000 employees must allocate 50 percent of the board seats to employees and 50 percent to shareholders. In firms with 500 2,000 employees, labor receives one-third of the board seats. Thus, in larger German firms, employees can-via the supervisory board-directly influence executive compensation and consequently their outrage costs may be particularly relevant. 
Finally, federal, state and local governments have traditionally been significant shareholders. In such a setting, public outrage may directly find its way into executive compensation via government representatives on the supervisory board. Moreover, the federal government recently also engaged in the regulation of executive compensation. Since 2009, a law (Vorst AG) requires executive compensation to be "appropriate". Specifically, appropriateness, as defined by the law, requires compensation to be "customary", i.e., comparable to other executives in similar positions and industries, to include a cap for "extraordinary" events and, particularly, to be linked to the performance of the executives (du Plessis et al., 2012). ${ }^{3}$ Thus, even though the concepts of fairness and appropriateness may not always be accurately separable, appropriateness seems to be mainly linked to pay-forperformance. In contrast, as we pointed out above, fairness mainly relates to a distributive justice perspective and necessarily includes the consideration of multiple persons and their relative positions. Therefore, it is broader in scope than the question of an appropriate link of compensation to performance. To investigate outrage constraints, we consider the broader concept of fairness to be more helpful, as it more comprehensively captures concerns of stakeholders about absolute executive compensation amounts.

\section{THEORY DEVELOPMENT}

\section{(i) Theoretical Foundations}

The consideration of stakeholders' fairness concerns in executive compensation or, vice versa, the analysis of outrage if these concerns are not met would be relatively simple if there was a unanimous opinion among stakeholders about the fair amount of executive compensation. However, even though many individuals exhibit fairness preferences (Güth et al., 1982; Konow 1996), individual definitions of fairness are usually subjective and ambiguous (Cappelen et al., 2005). Moreover, as we will argue below in more detail, theories from social psychology

\footnotetext{
${ }^{3}$ Additionally, this law introduced the possibility of a non-binding say-on-pay shareholder vote.
} 
even imply that stakeholder opinions vary systematically with their personality traits. Therefore, we predict that stakeholder opinions on fair executive compensation are characterized by substantial variation, and a unanimous fair amount does not exist:

H1: There is substantial variation in opinions among stakeholders about the amount of fair executive compensation.

If there is no single fair amount that firms can choose to meet all stakeholder preferences, any given amount is likely to be too low for some but too high for other stakeholders. However, if the dispersion of stakeholder opinions was pure (white) noise, i.e., if none of the variation was systematically explained by predictable stakeholder characteristics, a fair amount would still exist for each firm based on the average opinion from a random sample of stakeholders. In other words, if the dispersion was pure noise, an "objective" fair compensation amount for each firm would exist at an aggregated level, independent of a firm's relevant stakeholders.

However, in the following, we draw on theories from social psychology to propose that opinions on fair compensation vary systematically with stakeholders' personality traits, defined as stable human dispositions regarding their way of thinking, feeling, and acting (McCrae and Costa, 1997). As we explain in more detail below, we first propose that stakeholders apply self-serving interpretations of distributive fairness when forming opinions on fair executive compensation amounts. Babcock and Loewenstein (1997, p. 110) state that individuals conflate "what is fair with what benefits oneself". These egocentric interpretations typically arise when the interpretation of outcomes is ambiguous (Thompson and Loewenstein, 1992), like in the case of fair executive compensation for which no clear benchmark exists.

Second, we propose that personality traits that are associated with individuals' attitudes toward risky outcomes could indirectly bias opinions on fair compensation amounts. Specifically, we assume that different levels of compensation risk are implied in individuals' opinions about the amount, so that a higher compensation risk justifies a higher fair amount. This is consistent with higher risk premiums for executives when risk increases. Social 
projection theory (Krueger and Clement, 1997; Ross et al., 1977; Taft, 1955) suggests that individuals over-generalize their own traits when making inferences about others and disregard others' actual traits and preferences (Ludwig and Nafziger, 2011; Van Boven and Loewenstein, 2003). If stakeholders over-generalize their own risk attitude to executive compensation, their own risk attitudes may indirectly increase fair compensation amounts via increased preferences for variable compensation.

Overall, the following predictions imply that even at an aggregated level, opinions on fair amounts of executive compensation and outrage potential are not independent of stakeholder (or shareholder) composition but contingent on the involved stakeholders' personality traits.

\section{(ii) Determinants of Opinions on Fairness of Executive Compensation Amounts}

(a) Perceived Similarity with Executives

We predict that stakeholders exhibit an egocentric fairness bias when forming an opinion on fair executive compensation amounts (Babcock et al., 1995; Messick and Sentis, 1979). Specifically, the higher the perceived similarity of stakeholders with executives, the higher should be the fair amounts of executive compensation. That means, the more they perceive themselves to possess management skills, the closer they feel to the group whose compensation they are judging and the higher they perceive a fair compensation to be.

There can be two nonmutually exclusive reasons for this (Adams, 1965). First, individuals feeling more similar to executives may assume higher executive inputs for self-serving reasons (Babcock and Loewenstein, 1997). Second, individuals who feel more similar to executives may tend to value a given executive input more highly. Both reasons likely lead to a higher perceived value of executive inputs which, according to the equity principle, would increase the amounts of executive compensation that are considered fair. We formally state this as $\mathrm{H} 2$ :

H2: A higher perceived similarity with executives is positively associated with the amounts of executive compensation that are considered fair.

(b) Preferred Executive Compensation Risk 
Different opinions on fair executive compensation may also arise because individuals are likely influenced by their different preferences for executives' compensation risk when forming opinions on what amount they deem fair. These differences are likely to carry over to fair compensation amounts because - under the assumption that executives are risk averseindividuals are likely willing to grant higher compensation amounts when the share of variable compensation increases. The reason is that these higher amounts would serve as the executive's risk premium for carrying more risk. This prediction is consistent with our underlying fairness concept as distributive justice theories are based on individuals' net utility and not on expected total amounts (Adams, 1965).

For our prediction, we suggest that the structure of executive compensation and the perception of fair amounts are interrelated so that opinions on fair amounts imply a structure that reflects the compensation risk stakeholders would prefer as part of fair executive compensation. Thus, our formal hypothesis relates the preferred variable share to stakeholders' opinions on fair compensation amounts:

H3: A higher preferred variable compensation share is positively associated with the amounts of executive compensation that are considered fair.

\section{(iii) Determinants of the Preferred Executive Compensation Risk ${ }^{4}$}

As the preference for executives' compensation risk likely affects the fair amount of executive compensation, any personality trait related to the preferred variable compensation share would indirectly affect the fair amount. We use social projection theory (Ross et al., 1977) to predict that three important personality traits that are associated with individuals' attitude toward risky outcomes (general risk tolerance, optimism, and competitiveness) may influence stakeholders' preferred structure of executive compensation even though the inherent risk

\footnotetext{
${ }^{4}$ In the following, we use preferences for variable compensation as a proxy for stakeholders' preferred executive compensation risk. In particular, we use the variable target compensation share (the ex ante portion of variable compensation that would be paid in case of $100 \%$ target achievement) and not the actual share to control for variation in assumed target achievements.
} 
does not affect them personally.

First, higher variable compensation increases the uncertainty of an executive's expected future income. Higher personal risk tolerance, however, should be associated with a higher acceptance of variable compensation. This is consistent with experimental evidence on workers' self-selection into different payment schemes (Chow, 1983; Dohmen and Falk, 2011). Thus, owing to social projection, the higher a stakeholder's own risk tolerance, the higher should be the preferred variable executive compensation share.

Second, research in psychology suggests that individuals exhibit varying degrees of optimism when predicting future outcomes (e.g., Scheier and Carver, 1985; Weinstein, 1980). More optimistic individuals focus more on the positive aspects of risk and, therefore, via social projection, should prefer higher variable compensation shares for executives.

Third, individuals' preferences for the interpersonal distribution of rewards, i.e., the preference for egalitarianism vs. competitiveness, may also be related to the preferred share of variable compensation. Specifically, egalitarian individuals should lean more toward compensation schemes leading to more equal rewards, whereas competitive individuals should lean toward compensation schemes leading to greater inequalities in rewards. This is consistent with prior experimental evidence on self-selection into competitive vs. egalitarian compensation (Bartling et al., 2009; Dohmen and Falk, 2011). As compensation schemes with a larger variable share lead to more unequal rewards, more competitive individuals are likely to prefer a larger variable compensation share.

Finally, we suggest that optimism and competitiveness interact in their effect on the preferred variable compensation share. That is, the effect of increased competitiveness on the preferred variable share is larger, the more optimistic an individual is. For instance, when someone is highly optimistic, higher competitiveness is likely to increase the preferred variable pay by a larger extent because the focus on positive outcomes increases the perceived benefits of the unequal distribution of rewards. 
We, therefore, make the following formal predictions:

H4: Stakeholders' preferred variable target compensation share in executive compensation is...

a. ...positively associated with higher personal risk tolerance,

b. ...positively associated with higher personal optimism,

c. ...positively associated with higher personal competitiveness, and

d. ...more positively associated with personal competitiveness the higher personal optimism is.

\section{(iv) Differences between Eligible Voters and Investment Professionals}

In addition to personality differences that are independent of individuals' affiliation to a stakeholder group, there might be differences in perceptions of fair executive compensation amounts between stakeholder groups as well. In particular, as prior research has discussed whether professionals' judgments may be affected by their job experience (Hopkins, 1996; Libby et al. 2002), investment professionals' capital market background and their (possibly) higher familiarity with the matter of executive compensation likely affect their perspective on executive compensation. However, it is unclear whether this perspective also affects their opinions on "fair" amounts as prior research finds similar fairness perceptions of professionals and the general public (e.g., Singer 1996). Moreover, investment professionals likely belong to a different socio-economic group with higher income and education than the average eligible voter. While this aspect might imply higher "fair" compensation amounts from investment professionals, it is unclear, overall, how their fairness opinions differ from those of eligible voters. Thus, we present our last hypothesis in the null form:

H5: The amounts of executive compensation that are considered fair by investment professionals do not differ from the amounts considered fair by eligible voters.

\section{METHODOLOGY}

\section{(i) Data Collection}

We conducted two surveys to collect data for our two stakeholder groups. First, we surveyed a 
representative random sample of eligible voters in the state of Hamburg via a computerassisted telephone interview. The survey was part of a broader representative study about various opinions and attitudes of eligible voters, which is regularly conducted by the social science department of a large public university located in Germany. All questions were checked for comprehensibility by "GESIS - Leibniz-Institute for the Social Sciences". The survey was conducted from mid-May to the end of June 2013. ${ }^{5}$ The survey population consists of all residents of the state of Hamburg over the voting age of $16 .{ }^{6}$ The random sample was selected using the Gabler-Häder-random procedure for representative telephone interviews. To include potential nonlisted telephone numbers into the survey, the procedure randomizes the last two digits of listed telephone numbers. The average interview time was 30 minutes. Participation was not incentivized, but the interviewers emphasized that participation was important as it offered the opportunity to state personal opinions on current political issues. 671 participants completed the standardized questionnaire. Participants were on average 51.4 years old, and 55\% were female. ${ }^{7}$

Second, we conducted an online survey among investment professionals. The survey targeted members of a professional association for German investment professionals, including a variety of professions in the investment industry like, for example, financial analysts and asset managers. Invitation links were sent by e-mail to 1,453 members of the association in early November 2013, followed by two reminders. In total, we received 140

\footnotetext{
${ }^{5}$ To ensure that our results from both surveys are not influenced by any recent major media story related to executive compensation during the survey period, we conduct a keyword search in the GENIOS press-archive database covering 183 major German newspapers with a total circulation of over 26 million copies per issue. We use the keywords "manager" and "compensation/remuneration", "CEO" and "compensation/remuneration," "manager" and "bonus(es)", "compensation scandal", and "manager" and "rip-off" for the time of the survey periods as well as two month before each survey. The search yields 4,777 press articles, of which 755 articles relate to executive compensation in a specific firm. Three independent raters find that 164 articles have a negative tone, 545 have a neutral tone, and 46 have a positive tone. Inter-rater reliability meets accepted reliability thresholds with Krippendorff's alpha equal to 0.71 (Hayes and Krippendorff, 2007; Krippendorff, 2004). The small number of positive and negative articles suggests that survey participants are unlikely to be influenced by a particularly positive or negative media story related to executive compensation.

${ }^{6}$ Since 2013, the voting age for state and local elections in Hamburg is 16. All results remain unaffected if we exclude survey participants below the age of 18 , which is the voting age for national elections in Germany.

${ }^{7}$ While the average age of the population of Hamburg was 42.2 years at that time, the average age of eligible voters was considerably higher.
} 
surveys until mid-December, resulting in a response rate of $9.6 \%$. The mean age was 44.5 years, and the mean work experience in the investment industry was 19.2 years with no participant having less than four years of work experience.

\section{(ii) Variable Measurement}

(a) Dependent Variables

We measure fairness considerations of executive compensation in two ways. First, we measure the amount of executive compensation that survey participants consider fair (COMP_FAIR). Second, we measure the maximum annual amount of compensation that participants would find acceptable (COMP_UNFAIR). We use these variables in our tests of H1-H3.

To avoid noise in the measurement of our dependent variables that is due to participants' heterogeneous assumptions about firm characteristics such as firm performance, size, or the executive's role, we measure our variables for a representative CEO. Specifically, we asked participants to refer to the CEO of an "average" DAX30-firm, i.e., the average of the 30 largest exchange-listed German firms. For this purpose, we provided participants with the net income and number of employees of the "average" DAX30-firm in 2012. Additionally, we pointed out that CEO compensation usually consists of a fixed salary and variable bonus payments to ensure that participants would state amounts for total compensation.

Participants were then asked to specify which annual amount of compensation they would consider fair for the CEO of such a firm and to state a euro amount per year (COMP_FAIR). Additionally, we elicited COMP_UNFAIR by asking: "Irrespective of the CEO's performance, what do you think: Above which total amount would you no longer consider the compensation fair?"8 We additionally measure COMP_UNFAIR as prior research indicates that small deviations from an amount that individuals consider fair do not make such an amount unacceptable but large deviations do (Camerer, 2003; Sanfey et al., 2003). Therefore,

\footnotetext{
${ }^{8}$ As we pointed out above, our underlying fairness concept captures a large variety of opinions on fair compensation amounts. Therefore, we did not specify which fairness criteria participants should refer to when indicating COMP_FAIR and COMP_UNFAIR.
} 
the "maximum acceptable amount" captured by COMP_UNFAIR indicates an individual's upper acceptance threshold and therefore proxies for stakeholders' outrage threshold.

To measure participants' preferred executive compensation risk, we asked participants which variable target compensation share (VAR_SHARE) should be included in executive compensation. To avoid varying assumptions about firm performance, we told participants to assume that the firm had average success and achieved all targets.

Finally, we also measured participants' estimate of a CEO reservation wage by asking what they estimate to be the minimum annual compensation amount that a particularly capable CEO would request to manage the average DAX30-firm (COMP_REQUEST). This estimate might reveal governance concerns regarding rent extraction when compared to estimates of the actual average compensation of a DAX30-CEO (COMP_ACTUAL). ${ }^{9}$ The latter can also provide insights into public knowledge about compensation practice in general. (b) Explanatory Variables

To test $\mathrm{H} 2$ and $\mathrm{H} 4 \mathrm{a}-\mathrm{H} 4 \mathrm{~d}$, we collect the following personality trait variables from our sample of eligible voters. Owing to time restrictions of the investment professionals in our online survey, we were not able to collect these variables for this sample and, hence, confine the associated hypotheses tests to the sample of eligible voters.

To measure participants' perceived similarity with executives (SIMILARITY), we used participants' assessment of their own management skills using the Strength of Personality Scale developed by Noelle-Neumann (1985). We argue that the personality strength factors are highly descriptive of management skills and, therefore, are a valid proxy for the perceived similarity with executives. ${ }^{10}$ The factors we include are "responsibility" ("I like taking on

\footnotetext{
${ }^{9}$ Shortly before the first survey began, the DSW (Deutsche Schutzvereinigung für Wertpapierbesitz e.V.) published a study (DSW, 2013) on the amounts of executive compensation paid in DAX30-firms in 2012. The average amount that was very close to the one derived from our own analyses of the 2012 annual statements of DAX30-firms was prominently communicated in the public media in Germany.

${ }^{10}$ Weiman $(1991,1994)$ validates the personality strength scale by providing evidence that individuals scoring high in personality strength are influential people with central network positions as it is common for managers. Since then, the scale has also been widely used to identify opinion leaders (e.g., Scheufele and Shah, 2000; Nisbet and Kotcher, 2009; Schenk and Rössler, 1997).
} 
responsibility”), "persuasiveness" (“I like convincing others of my opinion”), "role model” (“I often notice that others follow my actions"), "authority" ("I can make my point"), and "sense of being ahead" ("I am often one step ahead of others"). We asked participants for their agreement with these statements on a four-point scale from 1 ("fully disagree") to 4 ("fully agree"). To construct SIMILARITY, we use a formative index across the five items (Bisbe et al., 2007; Diamantopoulos and Winkelhofer, 2001). ${ }^{11}$

We mainly rely on single-item measures for the remaining personality traits as potential respondent fatigue in our telephone survey constrains the interview time to 20 to 30 minutes (Lavrakas, 1993). To measure risk tolerance (RISK_TOL), we ask participants to indicate how risk tolerant they are on a Likert scale from 0 ("not risk tolerant at all") to 10 ("very risk tolerant"). Sociological panel research has validated such holistic single-item measures as a stable personality trait reflecting individuals' attitude toward risk (Dohmen et al., 2005; The German Socio-Economic Panel Study, 2013).

For the other two attitudes toward risky outcomes, we measure participants' agreement with various statements on a four-point scale from 1 ("fully disagree") to 4 ("fully agree"). For optimism (OPTIMISM), we follow established measures of dispositional optimism by using generalized outcome expectancy (Scheier and Carver, 1985): "Usually, I expect that my personal affairs will turn out to be successful.” Competitiveness (COMPET) reflects a preference for egalitarian vs. competitive outcomes (Bartling et al., 2009; Dohmen and Falk, 2011). To proxy for competitiveness, we use a formative index of two facets of individuals' self-perception of having relatively superior skills compared to others. First, we measure participants' disposition to take on leadership positions in groups with the following

\footnotetext{
${ }^{11}$ Results from our additional survey, referenced in footnote 2, show that - while controlling for demographic variables - similarity with executives is significantly associated with participants' agreement to the equity principle (logistic regression coefficient $=0.37, \mathrm{p}<0.01)$ and perceived inputs of executives (OLS-regression coefficient $=0.22, \mathrm{p}<0.01)$. Both are important aspects of our underlying fairness concept. Thus, this finding supports the view that opinions about fair executive compensation are likely influenced by different interpretations of distributive justice.
} 
statement: "I like taking the lead in collective activities." Second, we measure confidence in developing better solutions or leading better than others: "I often give advice and make recommendations to others." These two aspects are based on prior research providing evidence that competitiveness and leadership are positively related (House and Howell, 1992) and that high levels of confidence influence choices to enter competition (Bartling et al., 2009).

(c) Control Variables for the Eligible Voters Sample

We employ a series of control variables to account for contextual factors that might affect the dependent variables in our models. First, we measure participants' exposure to business news (NEWS). Participants indicate whether they followed the business news within the last three months $(0=$ no, $1=$ yes $)$. Second, we measure EDUCATION as participants' highest educational degree at six levels $(1=$ no degree, $2=$ degree after nine years of school, $3=$ degree after 10 years of school, $4=$ high school degree after 12 years, $5=$ high school degree after 13 years, qualifying for university admission, $6=$ college/university degree). Third, INCOME is measured by participants' monthly net household income ${ }^{12}$ in euros on a nonlinear eight-point scale $(1=0-500,2=501-1,000,3=1,001-1,500,4=1,501-2,000,5=$ $2,001-3,000,6=3,001-4,000,7=4,001-5,000,8=5,000$ and more). Finally, GENDER is coded as 0 (male) and 1 (female), and AGE measures participants' age in years.

(d) Control and Additional Variables for the Investment Professionals Sample In addition to AGE, we included two variables that indicate investment professionals' experience. COVERAGE measures their familiarity with executive compensation in the reference group of DAX30-firms on a seven-point Likert scale, and EXPERIENCE measures job experience in years. We also include participants' profession and country they work in.

In addition to our main dependent variables described above, we collect additional data on investment professionals' perceived relevance of different fairness- and economics-based

\footnotetext{
${ }^{12}$ We use household income instead of personal income as the former represents a better proxy for an individual's economic situation and access to economic resources (Bartolini et al., 2013; Vendrik and Woltjer, 2007).
} 
criteria for the evaluation of executive compensation. Specifically, we asked investment professionals to indicate their agreement to the following four statements on a seven-point Likert scale from 1 ("fully disagree") to 7 ("fully agree"). FAIR_A: "It is important to me that the absolute total amount of executive compensation is fair." FAIR_B: "It is important to me that the absolute total amount does not exceed a threshold that I consider no longer acceptable." PPS: "It is important to me that executive compensation is closely related to changes in the firm value." RISK_PREM: "It is important to me that a higher executive compensation is only granted when the CEO carries more risk in return." FAIR_A refers to the general relevance of fairness as a criterion for executive compensation, whereas FAIR_B relates to the maximum acceptable amount. PPS and RISK_PREM relate to two economicsbased criteria. PPS measures the importance of pay-for-performance sensitivity (Core and Guay, 1999; Jensen and Murphy, 1990), and RISK_PREM refers to higher executive compensation as a risk premium (Feltham and Xie, 1994; Milgrom and Roberts, 1992).

\section{RESULTS}

\section{(i) Descriptive Statistics}

Table 1 reports summary statistics for all dependent, explanatory, and control variables for the eligible voters sample, and Table 2 provides the same information for investment professionals. To limit the effect of outliers in the subsequent analysis, we conduct a $95 \%$ winsorization for all variables related to compensation amounts in the eligible voters sample and a $98 \%$ winsorization in the investment professionals sample. ${ }^{13}$

\section{-- Insert Table 1 and Table 2 about here --}

Table 1 shows that 465 of 671 eligible voter participants (69\%) stated an opinion on the

\footnotetext{
${ }^{13}$ Our hypotheses tests are statistically and inferentially unaffected for various winsorization levels $(90 \%-96 \%$ for eligible voters and 90\%-no winsorization for investment professionals). When using 99\% winsorization or no winsorization in the eligible voters sample, our hypotheses are also statistically supported when removing participants who stated amounts above $€ 50 \mathrm{~m}$ as „fair" (three observations) or ,unfair“" (ten observations). Regarding our null hypothesis, exclusion of these outliers by and large confirms the mixed evidence that we present in our main analysis.
} 
fair amount of executive compensation (COMP_FAIR) and 73\% stated an opinion on the maximum acceptable amount (COMP_UNFAIR). The remaining participants decided not to answer the question, indicated no exact amount, or mentioned that they could make no generalized statement about a fair amount of compensation. As reported in Table 2, $70 \%$ of the investment professionals provided an opinion on COMP_FAIR, and 78\% did so for COMP_UNFAIR. Only a very small fraction of those not providing an answer indicated that fairness is not a relevant criterion for executive compensation. We consider this as first evidence that fairness matters for investment professionals as well.

Those voters who stated an opinion, on average, find that $€ 1.38 \mathrm{~m}$ is a fair amount of executive compensation (COMP_FAIR). The maximum acceptable amount (COMP_UNFAIR) of this stakeholder group is distinctly higher with $€ 4.13 \mathrm{~m}$ on average. A similar pattern, but on a generally higher level, is shown by the opinions of investment professionals with mean values of $€ 2.44 \mathrm{~m}$ (COMP_FAIR) and $€ 7.04 \mathrm{~m}$ (COMP_UNFAIR). Both measures seem widely dispersed. We will analyze this dispersion in more detail in the hypotheses tests.

Descriptive statistics for the preferred variable compensation share (VAR_SHARE) as reported in Table 1 and Table 2 again indicate a large variation within and between the stakeholder groups. While eligible voters prefer $21.1 \%$ on average, investment professionals prefer $41.2 \%$. Thus, they prefer significantly more compensation risk for executives $(t=9.98, p$ $<0.001)$. To put these preferences into perspective, we gathered data on the structure of variable and fixed compensation from the 2012 compensation reports of the DAX30-firms. In contrast to stakeholders' preferred variable compensation share, the actual average variable target compensation share was $69 \%$ (based on 15 out of 30 firms), and the realized variable compensation share of all DAX30-firms was 67\%.

Table 3 reports the Pearson correlations between all variables from the eligible voters sample. The correlations provide first evidence in favor of our hypotheses. First, VAR_SHARE and SIMILARITY are significantly positively correlated with COMP_FAIR 
and COMP_UNFAIR. Second, RISK_TOL, OPTIMISM, and COMPET are significantly positively correlated with VAR_SHARE. Generally, all correlations are not sufficiently high to warrant concerns about multicollinearity.

-- Insert Table 3 about here --

\section{(ii) Hypotheses Tests}

To test $\mathrm{H} 1$ predicting substantial variation in opinions among stakeholders about the amount of fair executive compensation, we analyze the dispersion of statements of COMP_FAIR within each stakeholder group. For eligible voters, the values for the $10^{\text {th }}$ and $90^{\text {th }}$ percentile of COMP_FAIR are $€ 100,000$ and $€ 3.50 \mathrm{~m}$. Similarly, for the investment professionals, these values are $€ 500,000$ and $€ 5.00 \mathrm{~m}$. In both samples, standard deviations are quite high resulting in coefficients of variation of $162 \%$ (eligible voters) and $86 \%$ (investment professionals).

Similar to COMP_FAIR, we also find substantial variation in both samples regarding our second main dependent variable COMP_UNFAIR. In the sample of eligible voters, the values for the $10^{\text {th }}$ and $90^{\text {th }}$ percentile are $€ 120,000$ and $€ 10.00 \mathrm{~m}$. In the investment professionals sample, they are $€ 500,000$ and $€ 15.00 \mathrm{~m}$. The coefficients of variation are $220 \%$ and $92 \%$. Together, we consider H1 supported and conclude that there is no unanimous opinion on what fair executive compensation is.

To test our remaining hypotheses, except for $\mathrm{H} 3$, we have to refer to the sample of eligible voters only, for which we were able to gather data on all dependent, explanatory, and control variables. We run OLS regressions using alternative models with and without control variables. To correct for heteroscedasticity, we calculate robust standard errors in all regressions using the Huber-White estimator. ${ }^{14,15}$

Table 4 displays the results of our regressions used to test $\mathrm{H} 2$ and $\mathrm{H} 3$. As dependent

\footnotetext{
${ }^{14} \mathrm{P}$-values reported are one-tailed for directional hypotheses tests and two-tailed otherwise.

${ }^{15}$ Since COMP_FAIR and COMP_UNFAIR are lower bounded, we re-run all regressions that test $\mathrm{H} 2$ and $\mathrm{H} 3$ with log-transformed dependent variables as a robustness check. With one exception (using COMP_UNFAIR to test $\mathrm{H} 2$ ), the results are robust and our conclusions are not affected by this transformation.
} 
variables, we use both COMP_FAIR and COMP_UNFAIR. Models (1) and (3) only include SIMILARITY and VAR_SHARE as explanatory variables while Models (2) and (4) include additional control variables. All four models included in Table 4 support $\mathrm{H} 2$ and $\mathrm{H} 3$ predicting that the fair amount is positively associated with the perceived similarity with executives ( $p<0.05$ in Models (1) to (3) and $p=0.087$ in Model (4)) and the preferred variable compensation share $(\mathrm{p}<0.01$ in all cases). The control variables reveal that women perceive lower amounts of executive compensation as fair than men and that exposure to business news significantly increases the fair amount but not the threshold amount. ${ }^{16}$ Education and income do not significantly affect opinions on both amounts. The latter finding indicates that envy is unlikely to influence perceptions of fair executive compensation. ${ }^{17}$

\section{-- Insert Table 4 about here --}

We also analyze the magnitudes of the reported effects. First, a one standard deviation change in SIMILARITY leads to a change of $18.6 \%$ in COMP_FAIR in Model (2) and 17.2\% in COMP_UNFAIR in Model (4). Similarly, a one standard deviation increase of VAR_SHARE increases both dependent measures by $40.7 \%$ and $36.2 \%$, respectively. Second, moving from the lowest to the highest observed levels of SIMILARITY and VAR_SHARE is associated with an absolute increase in COMP_FAIR of $€ 1.54 \mathrm{~m}$ and $€ 2.72 \mathrm{~m}$ as well as an increase in COMP_UNFAIR of $€ 4.26 \mathrm{~m}$ and $€ 7.24 \mathrm{~m}$. This analysis shows that our results not only have statistical but also economic significance.

\footnotetext{
${ }^{16}$ We also reran the regressions reported in Table 4 for two subsamples of participants who were either exposed to predominantly positive or negative business news and find that our tests of $\mathrm{H} 2$ and $\mathrm{H} 3$ are inferentially unaffected in both subsamples. Additionally, introducing interaction terms for SIMILARITY with NEWS (positive/negative) and VAR_SHARE with NEWS (positive/negative) into the regressions reported in Table 4 does not show any significant interaction ( $p>0.23$ in all cases). These results provide further evidence that participants' responses are unlikely to be influenced by exposure to recent good or bad business news.

${ }^{17}$ As an alternative measure for envy, we divided the estimated actual income of a CEO (COMP_ACTUAL) by the participants' annual net household income. We used the midpoint of each household income category as a euro amount. The larger this measure, the larger is the estimated executive compensation relative to the own income and consequently the more envious participants might be. That means, our proxy should be negatively associated with the dependent variable. However, if we substitute INCOME by this measure, we find no significantly negative association between this proxy and COMP_FAIR or COMP_UNFAIR, indicating that envy is not a major motive in opinions on executive compensation.
} 
Data from our sample of investment professionals lend additional support to H3. Table 5 shows regressions with and without control variables for COMP_FAIR and COMP_UNFAIR in this sample. Like for the eligible voters, VAR_SHARE has a significantly positive association with the stated compensation amount in all models ( $\mathrm{p} \leq 0.022$ in all cases).

\section{-- Insert Table 5 about here --}

Table 6 reports the results of our tests of $\mathrm{H} 4 \mathrm{a}-\mathrm{H} 4 \mathrm{~d}$. Model (1) includes the explanatory variables but excludes the interaction between OPTIMISM and COMPET predicted in H4d. It provides support for the positive association of personal risk tolerance with VAR_SHARE $(\mathrm{H} 4 \mathrm{a}, \mathrm{p}=0.011)$, the positive association of optimism $(\mathrm{H} 4 \mathrm{~b}, \mathrm{p}=0.097)$, and the positive association of competitiveness $(\mathrm{H} 4 \mathrm{c}, \mathrm{p}=0.044)$.

\section{-- Insert Table 6 about here --}

Model (2) adds the interaction between OPTIMISM and COMPET to test H4d and shows mean-centered interaction variables to report their partial effects. The interaction effect is positive and significant ( $\mathrm{p}=0.007)$, supporting $\mathrm{H} 4 \mathrm{~d}$. Model (3) additionally includes demographic variables and further supports our hypotheses. It also reveals that EDUCATION is significantly positively associated with VAR_SHARE $(p=0.014)$ and that women prefer lower variable compensation shares than men $(p=0.002) .{ }^{18}$

In terms of economic significance, a one standard deviation change in each of the three variables RISK_TOL, OPTIMISM, and COMPET leads to changes in VAR_SHARE between $6.9 \%$ and $7.6 \%$ from the mean. Moving from the lowest to the highest observed values of these variables increases VAR_SHARE, on an absolute basis, between 7 and 8 percentage points. Notably, all reported effects are incremental effects of each explanatory variable,

\footnotetext{
${ }^{18}$ We also analyzed whether participants' political philosophy affects our results. Therefore, we create a dummy variable, SOCIALIST, which equals 1 when voters' long-term affiliation to a political party favored one of the leftist parties that are usually characterized as attracting voters with more socialist attitudes (SPD, Linke, Grüne, Piratenpartei) and 0 otherwise. Including SOCIALIST into our regressions tabulated in Table 6 does not affect any of our inferences regarding H4a-d (not tabulated). Additionally, the coefficient of SOCIALIST is negative but not significant in any model (all p's $>0.10$ ). These results suggest that the effects of risk attitudes are neither captured nor confounded by political persuasion.
} 
holding constant all other variables in the model. Since our results on $\mathrm{H} 3$ indicate that preferences for the structure of executive compensation are interrelated with opinions on the fair amount, we also investigate the indirect impact of attitudes toward risky outcomes on the fair amount. Identifying two sub-groups within the sample of eligible voters indicates a large spread in stated amounts. Participants who scored below the median in RISK_TOL, OPTIMISM, and COMPET stated a mean COMP_FAIR of $€ 1.06 \mathrm{~m}$, while participants scoring above the median in all three traits stated $€ 1.87 \mathrm{~m}$. The corresponding spread for COMP_UNFAIR is $€ 2.87 \mathrm{~m}$ vs. $€ 6.84 \mathrm{~m} .{ }^{19}$

Taken together, our results indicate that fairness considerations about executive compensation not only exhibit a substantial variation but are also systematically biased into the direction of each participant's personality traits. As we will outline below, this can have implications for managing the constitution of the shareholder or stakeholder base in a firm.

Finally, we test H5. As indicated above, the differences in means of COMP_FAIR and COMP_UNFAIR between our two samples are substantial (COMP_FAIR: €2.44m vs. $€ 1.38 \mathrm{~m}$, COMP_UNFAIR: $€ 7.04 \mathrm{~m}$ vs. $€ 4.13 \mathrm{~m})$. These differences are significant (COMP_FAIR: $\mathrm{t}=4.29, \mathrm{p}<0.001$; COMP_UNFAIR: $\mathrm{t}=3.31, \mathrm{p}=0.001)$. However, to make the two samples more comparable with regard to the socio-economic background, we restrict the sample of eligible voters to participants with a college/university degree and a monthly household income of $€ 5,000$ or more and no longer find any significant difference with regard to COMP_FAIR (€2.44m vs. $€ 2.14 \mathrm{~m}: \mathrm{t}=0.72, \mathrm{p}=0.47)$ or COMP_UNFAIR (€7.04m vs. $€ 6.24 \mathrm{~m}: \mathrm{t}=0.53, \mathrm{p}=0.60$ ). Thus, our evidence regarding $\mathrm{H} 5$ is mixed and we cannot

\footnotetext{
${ }^{19}$ As previously shown, the preferred variable compensation share is smaller than the actual variable compensation share of our reference firms ( $21 \%$ vs. $69 \%)$. To illustrate the potential influence of this gap on outrage thresholds, we use the coefficient of VAR_SHARE $(€ 72,419)$ from Model $(4)$ of Table 4, multiply it by the size of the gap $48 \%(=69 \%-21 \%)$, and add it to the mean value of COMP_UNFAIR. The threshold increases by $€ 3.5 \mathrm{~m}$ to $€ 7.6 \mathrm{~m}$ in total. Similar calculations for the investment professionals indicate an increase from $€ 7.0 \mathrm{~m}$ to $€ 9.6 \mathrm{~m}$. Yet, it is unclear whether more salient disclosure of the executive compensation risk could help firms lower their outrage costs because a large gap between the preferred and actual variable compensation share, i.e., a large deviation from the stated preference, might require firms to convince stakeholders of the need for high variable compensation.
} 
conclusively reject the null hypothesis. Investment professionals indicate higher fair compensation amounts compared to eligible voters as a whole, but differences seem to be substantially smaller and insignificant if the latter sample becomes more comparable. This result indicates that investment professionals' capital market background per se does not seem to lead to perceptions of fair executive compensation that differ fundamentally from those of eligible voters with comparable socio-economic background.

\section{(iii) Supplementary Analysis}

(a) Fairness as a Criterion for Investment Professionals

To lend further support to the notion that fairness in executive compensation matters for investment professionals, we analyze the additional variables we measured for this sample (FAIR_A, FAIR_B, PPS, RISK_PREM). Descriptive statistics, displayed in Panel A of Table 2 , suggest that all criteria are highly important (all means $\geq 5.35$ ). Pairwise comparisons reveal that FAIR_A seems to be more important than FAIR_B (5.75 vs. 5.35, $\mathrm{t}=1.74, \mathrm{p}=0.084)$ but show no other significant differences. We also analyze the relative ranks of all criteria implied by participants' importance ratings. We find that the fairness criteria are ranked first (last) by $57 \%$ and $50 \%$ (25\% and $29 \%)$ of the participants, respectively, whereas the economic criteria are ranked first (last) by $54 \%$ and $49 \%$ (23\% and 34\%) of the participants. ${ }^{20}$ Pair-wise comparisons based on Wilcoxon tests indicate no significant differences (all $\mathrm{p}>0.10$ ). Moreover, even though the two fairness criteria are significantly correlated $(r=0.42, p<$ $0.001)$ as well as the two economic criteria $(r=0.24, p=0.004)$, none of the fairness criteria is significantly positively correlated with any of the two economic criteria $(p>0.10$ in all cases). This suggests that fairness constitutes an independent, but no less important, factor for investment professionals in addition to economic criteria. Yet, this does not preclude the possibility that other economic criteria may be more important for investment professionals.

\footnotetext{
${ }^{20}$ Due to assigning non-exclusive ranks, the aggregated frequency of a rank can exceed $100 \%$.
} 
(b) Outrage Potential from Eligible Voters and Investment Professionals

As we explained above, the maximum acceptable amount (COMP_UNFAIR) may be more relevant for the inclusion of fairness concerns and the measurement of outrage than COMP_FAIR. Specifically, it may be that outrage potential exists when a sufficiently high number of stakeholders perceive the amount of executive compensation as "unfairly" high. Therefore, we investigate how large such outrage potential would be for the "public opinion" (measured by eligible voters) and the "market opinion" (measured by investment professionals), for the actual compensation of all DAX30-CEOs in 2012. Specifically, we analyze for how many individuals in each sample a firm's actual CEO compensation exceeds the individual's maximum acceptable amount (COMP_UNFAIR).

As detailed in Appendix A, we find that for every firm, the outrage threshold of the majority of eligible voters is exceeded by the CEO's compensation amount. In contrast, this is only the case for half of the firms when examining the outrage thresholds of the investment professionals. This finding relates to the literature on press coverage as a measure of public outrage (e.g., Core et al., 2008) and draws a connection to shareholder voting behavior (e.g., Ferri and Maber, 2013) and the effectiveness of public outrage as a constraint. Specifically, if investment professionals are a better proxy for voting behavior at annual meetings and eligible voters are a better proxy for mass media coverage, our results show that press coverage might be a noisy indicator of shareholder action against executive compensation. Additionally, any disconnect between shareholder voting and press coverage may not indicate that investors do not care about fairness but may simply imply that their outrage thresholds are higher.

(c) Estimations of Actual Executive Compensation

An important prerequisite or, at least, facilitator for the emergence of outrage about executive compensation is transparency about it (Bebchuk and Fried, 2003). Therefore, we assess stakeholders' knowledge about compensation in practice. We use our participants' estimated compensation of the average DAX30-CEO in 2012 (COMP_ACTUAL). Note that this is the 
group of executives that dominates almost the entire public discussion about executive compensation. Yet, only $10 \%$ of eligible voters and $24 \%$ of investment professionals estimate an actual compensation amount that is within an interval of $+/-€ 1 \mathrm{~m}$ around the true average of $€ 5.19 \mathrm{~m}$. As Figure 1 illustrates, many participants under- or overestimate the actual amount by far, depicting a rather U-shaped distribution of eligible voters' estimates. Overall, the majority of eligible voters $(63 \%)$ and investment professionals $(83 \%)$ underestimate the actual amount. Even though investment professionals' estimates seem more accurate than eligible voters' estimates, ${ }^{21}$ the accuracy of both groups is still rather low. Furthermore, $35 \%$ of eligible voters and $8 \%$ of investment professionals did not provide any estimate.

\section{-- Insert Figure 1 about here --}

Overall, these results suggest that, knowledge of actual compensation is relatively scant, despite recent efforts to make disclosure more transparent. Additionally, as accurate knowledge about actual executive compensation is a prerequisite for outrage to emerge, our results also cast doubt on the current effectiveness of public outrage. ${ }^{22}$

\section{CONCLUSIONS}

This study investigates fairness concerns about executive pay levels of two stakeholder groups, eligible voters and investment professionals. In our survey, we ask both groups about their opinion on a "fair" amount as well as an outrage threshold and study their (potential) relation to outrage constraints. Thus, in contrast to prior research that has mainly related pay levels to governance concerns of investors (Brandes et al., 2008; McCahery and Sautner, 2012), our study provides evidence about fairness as an additional criterion and compares a broader "public" perspective (eligible voters) with a more "market"-based perspective

\footnotetext{
${ }^{21}$ We calculate the absolute deviation of each participant's estimate from the actual amount and find this deviation to be smaller for investment professionals $(€ 2.47 \mathrm{~m}$ vs. $€ 7.29 \mathrm{~m}$ : $\mathrm{t}=3.61, \mathrm{p}<0.001)$.

${ }^{22}$ Further comparison of COMP_ACTUAL and COMP_REQUEST (proxying for participants' estimate of the average CEO's reservation wage) point at governance concerns of both stakeholder groups related to executive rent extraction (a more detailed analysis is available from the authors on request). This result suggests that, in addition to fairness concerns, governance concerns can be an independent motive for stakeholder outrage.
} 
(investment professionals). Instead of examining the effect of outrage ex post (as, e.g., in Core et al., 2008), we study fairness concerns that likely indicate outrage potential as well as factors influencing such fairness concerns.

Our study draws an ambiguous picture about fairness and outrage constraints. First, the vast majority of both eligible voters and investment professionals exhibit fairness preferences about executive compensation. Thus, our findings imply that recent disclosure regulations on pay ratio disclosure (Dodd-Frank Act, Section 953(b)) that are related to stakeholders' notion of fairness seem warranted. Related to prior studies on outrage that analyze stakeholder reactions via say-on-pay voting dissent or press coverage (e.g., Ertimur et al., 2013; Kuhnen and Niessen, 2012), our approach adds the new perspective of ex-ante outrage potential.

Second, however, we also find that in both groups fairness opinions are widely dispersed such that it seems unrealistic to find a single "fair" amount of executive compensation that could satisfy most stakeholders. In fact, most amounts would be too low for some stakeholders and too high for others. Moreover, we find that these dispersed opinions on fairness are systematically biased by participants' personality traits. Specifically, in our sample of eligible voters, the opinions are influenced by self-serving interpretations of fairness and, indirectly, by attitudes toward risky outcomes. This finding implies that even on an aggregated level, it may not be possible to obtain a single "fair" amount of executive compensation because the personality traits of the involved stakeholders would influence this amount. The result also implies incentives for firms to manage the composition of involved stakeholder groups as some individuals seem to feel "more like the CEO" and justify higher entitlements. For instance, a family consortium and a hedge fund might vote differently not only for reasons of alignment of interest but also due to personality. From a research perspective, this insight might even explain how executives have used their power to sell their compensation as fair to shareholders and board members while the public might have disapproved. Additionally, our finding that such self-serving fairness interpretations apply to 
judgments affecting the wealth of an unrelated person also contributes to the literature on distributive justice theories because, previously, people have only been shown to make selfinterested fairness decisions about rewards that affect their own wealth (Konow, 2000). From a practical perspective, the same result might even have relevance for employment relations. In particular, the influence of potential employee outrage on pay setting might vary between firms in different industries and with different organizational structures (e.g., highly hierarchical vs. flat organizations) because the perceived similarity with executives may depend on the (dis)similarity of job profiles between management and rank and file employees that traditionally varies between industries and organizational structures.

Third, we examine the amounts above which individuals find executive compensation unfairly high and use them as a measure for outrage thresholds. Our results reveal that actual CEO compensation exceeds the outrage thresholds of the majority of voters for all DAX30firms, which serve as a reference group for our surveys, but exceeds the outrage thresholds of the majority of investment professionals for only half of the firms. The latter finding implies that, owing to perceived unfairness (and not governance concerns), high amounts of executive compensation may lead to shareholder activism at shareholder meetings. Additionally, our findings may explain why the link between "public outrage" in the mass media and "market outrage" at shareholder meetings has been found to be weak (Hooghiemstra et al., 2015). Hence, this result may shed further light on the limited impact of negative press coverage on executive compensation amounts (e.g., Kuhnen and Niessen, 2012).

Finally, we investigate participants' knowledge about actual executive compensation amounts and find that this knowledge is relatively scant for both eligible voters and investment professionals. It is thus unclear whether, despite recent efforts to improve transparency about executive compensation, current transparency mechanisms enable public outrage effectively. Therefore, standard setters and policy makers may want to carefully reconsider current transparency regulations and ways through which such information can be 
communicated to improve stakeholders' knowledge about executive compensation.

Our study is subject to some limitations and points to opportunities for future research. First, as we pointed out above, owing to its stakeholder culture and legal regulations, the German setting is particularly apt to analyze our questions. Even though our hypotheses are mainly related to the influence of personality traits on opinions on executive compensation and they are unlikely to be directionally affected by different views on firms in different countries, we simultaneously acknowledge that the German setting may limit the generalizability of our findings. Specifically, it would be important to investigate whether, in more shareholder oriented countries, the public as well as capital market participants exhibit similar concerns about the fairness of executive compensation and how high levels of fair and unfairly high compensation would be. Such future research may foster our understanding of outrage constraints and how they may be shaped by individual fairness perceptions.

Second, the design of our study does not allow comparing the importance of fairness as a judgment criterion between eligible voters and investment professionals directly and does not include all potential economic criteria. Future research could draw a more complete picture of the relevance of economic and fairness criteria for different stakeholder groups.

Despite these limitations, our study provides important insights into fairness considerations about executive compensation and how they might relate to outrage costs. 


\section{References}

Abowd, J.M. (1990), 'Does Performance-Based Managerial Compensation Affect Corporate Performance?', Industrial and Labor Relations Review, Vol.43 (Special Issue), pp. 52S-73S.

Abowd, J.M. and D.S. Kaplan (1999), 'Executive Compensation: Six Questions that Need Answering', The Journal of Economic Perspectives, Vol.13, pp. 145-168.

Adams, J.S. (1965), 'Inequity in Social Exchange', in L. Berkovitz (ed.), Advances in Experimental Social Psychology, Vol.2 (New York: Academic Press), pp. 267-299.

Alissa, W. (2015), 'Boards' Response to Shareholders' Dissatisfaction: The Case of Shareholders' Say on Pay in the UK', European Accounting Review, Vol.24, pp. 727752 .

Babcock, L., G. Loewenstein, S. Issacharoff and C. Camerer (1995), 'Biased Judgments of Fairness in Bargaining', The American Economic Review, Vol.85, pp. 1337-1343.

Babcock, L. and G. Loewenstein (1997), 'Explaining Bargaining Impasse: The Role of SelfServing Biases', The Journal of Economic Perspectives, Vol.11, pp. 109-126.

Baker, G.P., M.C. Jensen and K.J. Murphy (1988), 'Compensation and Incentives: Practice vs. Theory', The Journal of Finance, Vol.43, pp. 593-616.

Bartling, B., E. Fehr, M.A. Maréchal and D. Schunk (2009), 'Egalitarianism and Competitiveness', The American Economic Review, Vol.99, pp. 93-98.

Bartolini, S., E. Bilancini and F. Sarracino (2013), 'Predicting the Trend of Well-Being in Germany: How Much Do Comparisons, Adaption and Sociability Matter?’, Social Indicators Research, Vol.114, pp. 169-191.

Bebchuk, L.A. and J.M. Fried (2003), 'Executive Compensation as an Agency Problem', Journal of Economic Perspectives, Vol.17, pp. 71-92.

Bebchuk, L.A. and J.M. Fried (2004), Pay without Performance: The Unfulfilled Promise of Executive Compensation (Cambridge: Harvard University Press).

Bebchuk, L.A. and J.M. Fried (2005), 'Pay without Performance: Overview of the Issues', Journal of Applied Corporate Finance, Vol.17, pp. 8-22.

Bertrand, M. and S. Mullainathan (2001), 'Are CEOs Rewarded for Luck? The Ones without Principals Are’, The Quarterly Journal of Economics, Vol.116, pp. 901-932.

Bisbe, J., J.M. Batista-Foguet and R. Chenhall (2007), 'Defining Management Accounting Constructs: A Methodological Note on the Risks of Conceptual Misspecification', Accounting, Organizations and Society, Vol.32, pp. 789-820.

Brandes, P., M. Goranova and S. Hall (2008), 'Navigating Shareholder Influence: Compensation Plans and the Shareholder Approval Process', Academy of Management Perspectives, Vol.22, pp. 41-57.

Bruce, A., T. Buck and B.G.M. Main (2005), 'Top Executive Remuneration: A View from 
Europe', Journal of Management Studies, Vol.42, pp. 1493-1506.

Camerer, C. (2003), Behavioral Game Theory: Experiments in Strategic Interaction (Princeton: Princeton University Press).

Cappelen, A.W., A.D. Hole, E.O. Sorensen and B. Tungodden (2005), 'The Pluralism of Fairness Ideals: An Experimental Approach', The American Economic Review, Vol.97, pp. 818-827.

Chow, C.W. (1983), 'The Effects of Job Standard Tightness and Compensation Scheme on Performance: An Exploration of Linkages', The Accounting Review, Vol.58, pp. 667685.

Conyon, M. (2006), 'Executive Compensation and Incentives', Academy of Management Perspectives, Vol.20, pp. 25-44.

Conyon, M. (2014), 'Executive Compensation and Board Governance in US Firms', The Economic Journal, Vol.124, pp. 60-89.

Conyon, M., N. Fernandes, M. A. Ferreira, P. Matos and K. J. Murphy (2013), 'The Executive Compensation Controversy: A Transatlantic Analysis', in: Boeri, T., C. Lucifora and K.J. Murphy (eds.), Executive Remuneration and Employee Performance-Related Pay (Oxford: Oxford University Press), pp. 9-115.

Conyon, M. and G. Sadler (2010), 'Shareholder Voting and Directors' Remuneration Report Legislation: Say on Pay in the UK', Corporate Governance: An International Review, Vol.18, pp. 296-312.

Core, J.E. and W.R. Guay (1999), 'The Use of Equity Grants to Manage Optimal Equity Incentive Levels', Journal of Accounting and Economics, Vol.28, pp. 151-184.

Core, J.E., R.W. Holthausen and D.F. Larker (1999), 'Corporate Governance, Chief Executive Officer Compensation, and Firm Performance', Journal of Financial Economics, Vol.51, pp. 371-406.

Core, J.E., W.R. Guay and D.F. Larcker (2008), 'The Power of the Pen and Executive Compensation', Journal of Financial Economics, Vol.88, pp. 1-25.

David, P., R. Kochhar and E. Levitas (1998), 'The Effect of Institutional Investors on the Level and Mix of CEO Compensation', Academy of Management Journal, Vol.41, pp. 200-208.

Denis, D. K. and J. J. McConnell (2003), 'International Corporate Governance', The Journal of Financial and Quantitative Analysis, Vol.38, pp. 1-36.

Diamantopoulos, A. and H.M. Winkelhofer (2001), 'Index Construction with Formative Indicators: An Alternative to Scale Development', Journal of Marketing Research, Vol.38, pp. 269-277.

Dohmen, T. and A. Falk (2011), 'Performance Pay and Multidimensional Sorting: Productivity, Preferences, and Gender', The American Economic Review, Vol.101, pp. 556-590. 
Dohmen, T., A. Falk, D. Huffman, U. Sunde, J. Schupp and G.G. Wagner (2005), 'Individual Risk Attitudes: New Evidence From a Large, Representative, ExperimentallyValidated Study', IZA Discussion Paper No. 1730, Bonn.

DSW (Deutsche Schutzvereinigung für Wertpapierbesitz e.V.) (2013), Studie zur Vergütung der Vorstände in den DAX- und MDAX-Unternehmen im Geschäftsjahr 2012, München.

du Plessis, J.J., B. Großfeld, C. Luttermann, I. Saenger, O. Sandrock and M. Casper (2012), German Corporate Governance in International and European Context, $2^{\text {nd }}$ edition (Heidelberg: Springer-Verlag).

Edmans, A. and X. Gabaix (2009), 'Is CEO Pay Really Inefficient? A Survey of New Optimal Contracting Theories', European Financial Management, Vol.15, pp. 486-496.

Ertimur, Y., F. Ferri and D. Oesch (2013), 'Shareholder Votes and Proxy Advisors: Evidence from Say on Pay', Journal of Accounting Research, Vol.51, pp. 951-996.

Fauver, L. and M. E. Fuerst (2006), 'Does Good Corporate Governance Include Employee Representation? Evidence From German Corporate Boards', Journal of Financial Economics, Vol.82, pp. 673-710.

Feltham, G.A. and J. Xie (1994), 'Performance Measure Congruity in Multi-Task Principal/ Agent Relations', The Accounting Review, Vol.69, pp. 429-453.

Ferri, F. and D.A. Maber (2013), 'Say on Pay Votes and CEO Compensation: Evidence from the UK', Review of Finance, Vol.17, pp. 527-563.

Ferri F. and T. Sandino (2009), 'The Impact of Shareholder Activism on Financial Reporting and Compensation: The Case of Employee Stock Options Expensing', The Accounting Review, Vol.84, pp. 433-466.

Fiss, P.C. and E.J. Zajac (2004), 'The Diffusion of Ideas over Contested Terrain: The (Non)adoption of a Shareholder Value Orientation among German Firms', Administrative Science Quarterly, Vol.49, pp. 501-534.

Güth, W., R. Schmittberger and B. Schwarze (1982), 'An Experimental Analysis of Ultimatum Bargaining', Journal of Economic Behavior and Organization, Vol.3, 367388 .

Hartzell, J.C. and L.T. Starks (2003), 'Institutional Investors and Executive Compensation', The Journal of Finance, Vol.58, pp. 2351-2374.

Hayes, A.F. and K. Krippendorff (2007), 'Answering the Call for a Standard Reliability Measure for Coding Data', Communication Methods and Measures, Vol.1, pp. 77-89.

Hoffman, E. and M.L. Spitzer (1985), 'Entitlements, Rights, and Fairness: An Experimental Examination of Subjects' Concepts of Distributive Justice', The Journal of Legal Studies, Vol.14, pp. 259-297.

Hooghiemstra, R., Y.F. Kuang and B. Qin (2015), 'Say-on-Pay Votes: The Role of the Media', European Accounting Review, Vol.24, pp. 753-778. 
Hopkins, P.E. (1996), 'The Effect of Financial Statement Classification of Hybrid Financial Instruments on Financial Analysts' Stock Price Judgments', Journal of Accounting Research, Vol.34, pp. 33-50.

House, R.J. and J.M. Howell (1992), 'Personality and Charismatic Leadership', The Leadership Quarterly, Vol.3, pp. 81-108.

Jensen, M.C. and K.J. Murphy (1990), 'Performance Pay and Top-Management Incentives', Journal of Political Economy, Vol.98, pp. 225-264.

Johnson, M.F., S. Porter and M.B. Shackell (1997), 'Stakeholder Pressure and the Structure of Executive Compensation', Working Paper, Michigan State University, University of Virginia, Cornell University.

Kelly, K. and J.L. Seow (2016), 'Investor Reactions to Company Disclosure of High CEO Pay and High CEO-to-Employee Pay Ratio: An Experimental Investigation', Journal of Management Accounting Research, Vol.28, pp. 107-125.

Konow, J. (1996), ‘A Positive Theory of Economic Fairness', Journal of Economic Behavior and Organization, Vol.31, pp. 13-35.

Konow, J. (2000), 'Fair Shares: Accountability and Cognitive Dissonance in Allocation Decisions', The American Economic Review, Vol.90, pp. 1072-1091.

Konow, J. (2003), 'Which is the Fairest One of All? A Positive Analysis of Justice Theories', Journal of Economic Literature, Vol.41, pp. 1188-1239.

Krippendorff, K. (2004), 'Reliability in Content Analysis - Some Common Misconceptions and Recommendations', Human Communication Research, Vol.30, pp. 411-433.

Krueger, J. and R.W. Clement (1997), 'Estimates of Social Consensus by Majorities and Minorities: The Case of Social Projection', Personality and Social Psychology Review, Vol.1, pp. 299-313.

Kuhnen, C.M. and A. Niessen (2012), 'Public Opinion and Executive Compensation', Management Science, Vol.58, pp. 1249-1272.

Larcker, D.F. and B. Tayan (2011), Corporate Governance Matters: A Closer Look at Organizational Choices and Their Consequences (Upper Saddle River, NJ: FT Press).

Lavrakas, P.J. (1993), Telephone Survey Methods: Sampling, Selection, and Supervision, 2nd ed. (Newbury Park, CA: Sage Publications).

Libby, R., R. Bloomfield and M.W. Nelson (2002), 'Experimental Research in Financial Accounting', Accounting, Organizations and Society, Vol.27, pp. 775-810.

Ludwig, S. and J. Nafziger (2011), 'Beliefs About Overconfidence', Theory and Decision, Vol.70, pp. 475-500.

McCahery, J.A. and Z. Sautner (2012), 'Institutional Investor Preferences and Executive Compensation', in J. Hill and R. Thomas (eds.), Research Handbook of Executive Pay (Cheltenham, UK: Edward Elgar Publishing Ltd), pp. 241-254. 
McCrae, R.R. and P.T. Costa (1997), 'Personality Trait as a Human Universal', American Psychologist, Vol.52, 509-516.

Messick, D.M. and K.P. Sentis (1979), 'Fairness and Preference', Journal of Experimental Social Psychology, Vol.15, pp. 418-434.

Milgrom, P. and J. Roberts (1992), Economics, Organization and Management (Upper Saddle River: Prentice-Hall).

Murphy, K.J. (1999), 'Executive Compensation', in O. Ashenfelter and D. Card (eds.), Handbook of Labor Economics (Amsterdam: North-Holland), pp. 2485-2563.

Murphy, K.J. (2012), 'Executive Compensation: Where We Are, and How We Got There', in: G.M. Constantinides, M. Harris, and R.M. Stulz (eds.), Handbook of the Economics of Finance Vol.2A (Oxford: Elsevier Science North Holland), pp. 211-356.

Nisbet, M.C. and J.E. Kotcher (2009), 'A Two-Step Flow? Opinion Leadership on Climate Change', Science Communication, Vol.30, pp. 328-354.

Noelle-Neumann, E. (1985), 'Identifying Opinion Leaders', 38th ESOMAR Conference, Wiesbaden.

O'Brien, N. (2011), Just Deserts? Attitudes to Fairness, Poverty and Welfare Reform, URL: https://policyexchange.org.uk/publication/just-deserts-attitudes-to-fairness-povertyand-welfare-reform/. Last accessed 11/13/2017.

Page, B.I. and L.R. Jacobs (2009), Class War? What Americans Really Think About Economic Inequality (Chicago: University of Chicago Press).

Ross, L., D. Greene and P. House (1977), 'The "False Consensus Effect": An Egocentric Bias in Social Perception and Attribution Processes', Journal of Experimental Social Psychology, Vol.13, pp. 279-301.

Sanfey, A.G., J.K. Rilling, J.A. Aronson, L.E. Nystrom and J.D. Cohen (2003), 'The Neural Basis of Economic Decision-Making in the Ultimatum Game', Science, Vol.300, pp. $1755-1758$.

Scheier, M.F. and C.S. Carver (1985), 'Optimism, Coping, and Health: Assessment and Implications of Generalized Outcome Expectancies', Health Psychology, Vol.4, pp. 219-247.

Schenk, M. and P. Rössler (1997), 'The Rediscovery of Opinion Leaders. An Application of the Personality Strength Scale', Communications, Vol.22, pp. 5-30.

Scheufele, D.A. and D.V. Shah (2000), 'Personality Strength and Social Capital', Communication Research, Vol.27, pp. 107-131.

Schmidt, R.H. and M. Tyrell (1997), 'Financial Systems, Corporate Finance, and Corporate Governance', European Financial Management, Vol.3, pp. 333-361.

SEC (2006), 'Executive Compensation and Related Person Disclosure', Exchange Act

Release No. 33-8732A, URL: www.sec.gov/rules/final/2006/33-8732a.pdf. Last 
accessed 11/13/2017.

Simnett, R., A. Vanstraelen and W. Fong Chua (2009), 'Assurance on Sustainability Reports: An International Comparison', The Accounting Review, Vol.84, pp. 937-967.

Singer, M.S. (1996), 'The Role of Moral Intensity and Fairness Perceptions in Judgments of Ethicality: A Comparison of Professionals and the General Public', Journal of Business Ethics, Vol.15, pp. 469-474.

Taft, R. (1955), ‘The Ability to Judge People', Psychological Bulletin, Vol.52, pp. 1-23.

The German Socio-Economic Panel Study (2013), Survey instruments "Living in Germany": Individual questionnaire, URL:

http://www.diw.de/en/diw_02.c.238114.en/questionnaires_fieldwork_documents.html. Last accessed 11/13/2017.

Thompson, L. and G. Loewenstein (1992), 'Egocentric Interpretations of Fairness and Interpersonal Conflict', Organizational Behavior and Human Decision Processes, Vol.51, pp. 176-197.

Van Boven, L. and G. Loewenstein (2003), 'Social Projection of Transient Drive States', Personality and Social Psychology Bulletin, Vol.29, pp. 1159-1168.

Vendrik, M.C.M. and G.B. Woltjer (2007), 'Happiness and Loss Aversion: Is Utility Concave or Convex in Relative Income?', Journal of Public Economics, Vol.91, pp. 14231448 .

Weiman, G. (1991), 'The Influentials: Back to the Concept of Opinion Leaders?', Public Opinion Quarterly, Vol.55, pp. 267-279.

Weiman, G. (1994), The Influentials: People Who Influence People (Albany: State University of New York Press).

Weimer, J. and J. C. Pape (1999), 'A Taxonomy of Systems of Corporate Governance', Corporate Governance: An International Review, Vol.7, pp. 152-166.

Weinstein, N.D. (1980), 'Unrealistic Optimism about Future Life Events', Journal of Personality and Social Psychology, Vol.39, pp. 806-820. 


\begin{tabular}{|c|c|c|c|}
\hline Firm & $\begin{array}{l}\text { CEO compensation } \\
\text { in } 2012 \text { in } €\end{array}$ & Eligible voters & $\begin{array}{c}\text { Investment } \\
\text { professionals }\end{array}$ \\
\hline Commerzbank & $1,392,000$ & $63 \%$ & $13 \%$ \\
\hline Lufthansa & $2,281,000$ & $71 \%$ & $23 \%$ \\
\hline $\mathrm{K}+\mathrm{S}$ & $2,618,000$ & $72 \%$ & $25 \%$ \\
\hline Infineon & $2,900,000$ & $72 \%$ & $25 \%$ \\
\hline Continental & $2,934,000$ & $72 \%$ & $25 \%$ \\
\hline Deutsche Börse & $3,402,000$ & $74 \%$ & $31 \%$ \\
\hline Fresenius & $3,494,000$ & $74 \%$ & $31 \%$ \\
\hline Beiersdorf & $3,756,000$ & $75 \%$ & $32 \%$ \\
\hline RWE & $3,803,000$ & $75 \%$ & $32 \%$ \\
\hline ThyssenKrupp & $3,847,000$ & $75 \%$ & $32 \%$ \\
\hline Lanxess & $4,122,000$ & $76 \%$ & $34 \%$ \\
\hline Deutsche Telekom & $4,160,000$ & $76 \%$ & $34 \%$ \\
\hline Heidelberg Cement & $4,349,000$ & $76 \%$ & $34 \%$ \\
\hline Munich RE & $4,353,000$ & $76 \%$ & $34 \%$ \\
\hline Fresenius Medical Care & $4,428,000$ & $76 \%$ & $34 \%$ \\
\hline Bayer & $5,062,000$ & $84 \%$ & $61 \%$ \\
\hline BASF & $5,286,000$ & $84 \%$ & $61 \%$ \\
\hline Deutsche Bank & $5,306,000$ & $84 \%$ & $61 \%$ \\
\hline Deutsche Post & $5,457,000$ & $84 \%$ & $61 \%$ \\
\hline Merck & $5,549,000$ & $84 \%$ & $61 \%$ \\
\hline Allianz & $5,797,000$ & $84 \%$ & $61 \%$ \\
\hline E.ON & $5,961,000$ & $84 \%$ & $61 \%$ \\
\hline BMW & $6,627,000$ & $84 \%$ & $63 \%$ \\
\hline Henkel & $6,705,000$ & $84 \%$ & $63 \%$ \\
\hline Linde & $6,920,000$ & $84 \%$ & $63 \%$ \\
\hline Adidas & $7,286,000$ & $85 \%$ & $65 \%$ \\
\hline SAP & $7,349,000$ & $85 \%$ & $65 \%$ \\
\hline Siemens & $7,871,000$ & $85 \%$ & $65 \%$ \\
\hline Daimler & $8,153,000$ & $86 \%$ & $66 \%$ \\
\hline \multirow[t]{4}{*}{ Volkswagen } & $14,511,000$ & $94 \%$ & $90 \%$ \\
\hline & Lowest potential & $63 \%$ & $13 \%$ \\
\hline & Highest potential & $94 \%$ & $90 \%$ \\
\hline & Mean & $79 \%$ & $47 \%$ \\
\hline
\end{tabular}

Notes: The table shows the outrage potential of eligible voters and investment professionals for the CEO compensation in the 30 largest exchange-listed German firms (DAX30) in 2012. These firms represent the reference group for participants' stated amounts in our surveys. Compensation data was hand collected from the 2012 compensation reports. Firms are ordered from lowest to highest CEO compensation.

${ }^{a}$ Outrage potential: The percentage share of participants whose stated maximum acceptable amount lies below the respective firm's actual CEO compensation in 2012 (i.e., the compensation amount that was reported in early 2013). This measure captures outrage potential since exceeding the maximum acceptable amount may lead to disapproval strong enough to incite outrage. 


\section{Appendix B: Questionnaire - Telephone Survey among Eligible Voters ${ }^{23}$}

\section{Questions - Executive Compensation}

The media often covers the compensation of top managers. This coverage usually refers to the $\mathrm{CEO}^{24}$ compensation of the 30 largest German firms whose shares are traded on the stock exchange. On average, every so-called DAX firm had a net income of $€ 2.1$ billion in 2012. Furthermore, it employed about 130,000 people.

The compensation amounts that are referred to in the media usually reflect the total compensation that the CEO received within a year. These amounts include the fixed salary as well as variable bonus payments. Please refer to an average DAX firm for all following questions.

\section{COMP FAIR}

Which total annual amount of compensation would you consider fair for the CEO of such a firm? Please state a $€$-amount per year.

O EURO

O Don't know

O N/A

\section{COMP_UNFAIR}

Irrespective of the CEO's performance, what do you think: Above which total amount would you no longer consider the compensation fair? Please state again a $€$-amount per year.

O EURO

O Don't know

O N/A

\section{COMP_REQUEST}

Independent of your personal fairness preferences, what do you think: Which total amount of compensation would a particularly capable manager request at minimum for assuming the management of such a firm? Please state a $€$-amount per year.

$\mathbf{O}$ EURO

O Don't know

O N/A

\footnotetext{
${ }^{23}$ The questions presented in Appendix B are an excerpt from the original questionnaire that was used for the telephone survey among representative eligible voters. We translated all questions relevant to our study directly from German to be as close as possible to the original questions.

${ }^{24}$ In the German original, the term "Vorstandsvorsitzender" (chief executive officer) was used. To improve the readability of the English version of the survey, we use the abbreviation CEO in this translation.
} 
VAR_SHARE

The total annual amount of compensation of a CEO consists of a fixed salary and a bonus.

The CEO always receives the fixed salary. The variable bonus varies with the firm's performance. Now, please imagine the following situation: A firm finishes a fiscal year with average success, and all targets are achieved. In your opinion: What percentage should the bonus represent of the CEO's total compensation? Please state a percentage between 0 and 100 (for the bonus).

$\mathbf{O}$ $\%$

O Don't know

O N/A

COMP_ACTUAL

And what do you think: How large was the actual average total amount of compensation for the CEO of a DAX firm in the last year? Please state a $€$-amount per year.

$\mathbf{O}$ EURO

O Don't know

O N/A

\section{NEWS}

Did you hear or read about any positive or less positive news about the overall economic situation within the last three months?

O Yes, positive

O Yes, negative

O Yes, both

O No, neither positive nor negative

O Don't know

O N/A 
SIMILARITY

I now have some questions about your personal attitudes and will read several statements to you. Please tell me how much you personally agree with the following statements by indicating: "fully agree", "somewhat agree", "somewhat disagree", "fully disagree".

\begin{tabular}{l|cccc|cc|}
\hline & $\begin{array}{c}\text { Fully } \\
\text { disagree }\end{array}$ & $\begin{array}{c}\text { Somewhat } \\
\text { disagree }\end{array}$ & $\begin{array}{c}\text { Somewhat } \\
\text { agree }\end{array}$ & $\begin{array}{c}\text { Fully } \\
\text { agree }\end{array}$ & $\begin{array}{c}\text { Don't } \\
\text { know }\end{array}$ & N/A \\
\hline $\begin{array}{l}\text { I like taking on } \\
\text { responsibility. }\end{array}$ & $\mathbf{O}$ & $\mathbf{O}$ & $\mathbf{O}$ & $\mathbf{O}$ & $\mathbf{O}$ & $\mathbf{O}$ \\
$\begin{array}{l}\text { I like convincing others } \\
\text { of my opinion. }\end{array}$ & $\mathbf{O}$ & $\mathbf{O}$ & $\mathbf{O}$ & $\mathbf{O}$ & $\mathbf{O}$ & $\mathbf{O}$ \\
$\begin{array}{l}\text { I often notice that others } \\
\text { follow my actions. }\end{array}$ & $\mathbf{O}$ & $\mathbf{O}$ & $\mathbf{O}$ & $\mathbf{O}$ & $\mathbf{O}$ & $\mathbf{O}$ \\
$\begin{array}{l}\text { I can make my point. } \\
\text { I am often one step }\end{array}$ & $\mathbf{O}$ & $\mathbf{O}$ & $\mathbf{O}$ & $\mathbf{O}$ & $\mathbf{O}$ & $\mathbf{O}$ \\
ahead of others. & $\mathbf{O}$ & $\mathbf{O}$ & $\mathbf{O}$ & $\mathbf{O}$ & $\mathbf{O}$ & $\mathbf{O}$ \\
\hline
\end{tabular}

RISK_TOL

How risk tolerant are you? Please assess your own risk tolerance on a scale from zero to ten. Zero means: "I am not risk tolerant at all". Ten means: "I am very risk tolerant". With the numbers in between (one, two, three, four five, six, seven, eight, nine), you can rank your risk tolerance.

\begin{tabular}{|ccccccccccc|cc|}
\hline $\begin{array}{c}0 \text { (Not risk } \\
\text { tolerant at all) }\end{array}$ & 1 & 2 & 3 & 4 & 5 & 6 & 7 & 8 & 9 & $\begin{array}{c}10 \text { (Very } \\
\text { risk tolerant) }\end{array}$ & $\begin{array}{c}\text { Don't } \\
\text { know }\end{array}$ & N/A \\
\hline $\mathbf{O}$ & $\mathbf{O}$ & $\mathbf{O}$ & $\mathbf{O}$ & $\mathbf{O}$ & $\mathbf{O}$ & $\mathbf{O}$ & $\mathbf{O}$ & $\mathbf{O}$ & $\mathbf{O}$ & $\mathbf{O}$ & $\mathbf{O}$ & $\mathbf{O}$ \\
\hline
\end{tabular}

\section{OPTIMISM}

Please tell me how much you personally agree with the following statement by indicating: "fully agree", "somewhat agree", "somewhat disagree", "fully disagree".

\begin{tabular}{|l|cccc|cc|}
\hline & $\begin{array}{c}\text { Fully } \\
\text { disagree }\end{array}$ & $\begin{array}{c}\text { Somewhat } \\
\text { disagree }\end{array}$ & $\begin{array}{c}\text { Somewhat } \\
\text { agree }\end{array}$ & $\begin{array}{c}\text { Fully } \\
\text { agree }\end{array}$ & $\begin{array}{c}\text { Don't } \\
\text { know }\end{array}$ & N/A \\
\hline $\begin{array}{l}\text { Usually, I expect that my } \\
\text { personal affairs will turn } \\
\text { out to be successful. }\end{array}$ & $\mathbf{O}$ & $\mathbf{O}$ & $\mathbf{O}$ & $\mathbf{O}$ & $\mathbf{O}$ & $\mathbf{O}$ \\
\hline
\end{tabular}


Please tell me how much you personally agree with the following statements by indicating: "fully agree", "somewhat agree", "somewhat disagree", "fully disagree".

\begin{tabular}{|l|cccc|cc|}
\hline & $\begin{array}{c}\text { Fully } \\
\text { disagree }\end{array}$ & $\begin{array}{c}\text { Somewhat } \\
\text { disagree }\end{array}$ & $\begin{array}{c}\text { Somewhat } \\
\text { agree }\end{array}$ & $\begin{array}{c}\text { Fully } \\
\text { agree }\end{array}$ & $\begin{array}{c}\text { Don't } \\
\text { know }\end{array}$ & N/A \\
\hline $\begin{array}{l}\text { I like taking the lead in } \\
\text { collective activities. }\end{array}$ & $\mathbf{O}$ & $\mathbf{O}$ & $\mathbf{O}$ & $\mathbf{O}$ & $\mathbf{O}$ & $\mathbf{O}$ \\
$\begin{array}{l}\text { I often give advice and } \\
\text { make recommendations } \\
\text { to others. }\end{array}$ & $\mathbf{O}$ & $\mathbf{O}$ & $\mathbf{O}$ & $\mathbf{O}$ & $\mathbf{O}$ & $\mathbf{O}$ \\
\hline
\end{tabular}

\section{TRUST}

Generally speaking, do you think that most other people can be trusted or that you cannot be cautious enough when dealing with other people?

Please use a scale from zero to ten. Zero means "You cannot be cautious enough". Ten means: "You can trust most other people". With the numbers in between (one, two, three, four five, six, seven, eight, nine), you can rank your level of trust in others.

\begin{tabular}{|c|ccccccccc|c|cc|}
\hline $\begin{array}{c}0 \text { (You cannot } \\
\text { be cautious } \\
\text { enough) }\end{array}$ & 1 & 2 & 3 & 4 & 5 & 6 & 7 & 8 & 9 & $\begin{array}{c}10 \text { (You can } \\
\text { trust most other } \\
\text { people) }\end{array}$ & $\begin{array}{c}\text { Don't } \\
\text { know }\end{array}$ & N/A \\
\hline $\mathbf{O}$ & $\mathbf{O}$ & $\mathbf{O}$ & $\mathbf{O}$ & $\mathbf{O}$ & $\mathbf{O}$ & $\mathbf{O}$ & $\mathbf{O}$ & $\mathbf{O}$ & $\mathbf{O}$ & $\mathbf{O}$ & $\mathbf{O}$ & $\mathbf{O}$ \\
\hline
\end{tabular}




\section{GENDER}

[Interviewer: Check box without asking]

O Male

O Female

O Don't know

O N/A

\section{AGE}

Please state the month and year of your birth.

Month

Year

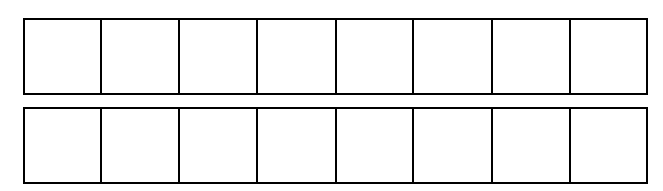

EDUCATION (composed of answers about school and college degree)

Which is the highest school degree that you have?

O Elementary school/did not finish secondary school

O Finished secondary school without degree/did not receive a degree yet (still in school)

O Degree after 9 years of school

O Degree after 10 years of school

O High school degree after 12 years

O High school degree after 13 years, qualifying for university admission

O Other degree:

O Don't know

O N/A

Which is the highest college/university degree that you have?

O Intermediate examination

O Diploma, university of cooperative education

O Bachelor, university of applied science

O Diploma, university of applied science

O Bachelor, university

O Master, university of applied science

O Diploma/state examination, university

O Master, university

O $\mathrm{PhD}$

O Other: 
O Don't know

O N/A

INCOME (composed of stated amount and categories)

What is the average monthly net income of your household? Be assured that your answer will not be linked to your name.

The average monthly net income of your household is the total amount that consists of wages, self-employment income, and retirement benefits. Please also consider social welfare benefits, income from rented property, investment income, housing benefits, family benefits, and other income and deduct taxes and social security contributions.

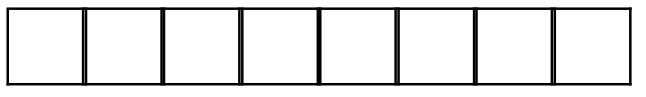

[If respondent is not sure about the exact amount]

We don't need to know the exact amount. This question should simply enable us to identify low-, medium- and high-income population groups. Therefore, we would like to learn what the average monthly net income of your household is. Be assured that your answer will not be linked to your name. I will now read out income groups to you. Please tell me in which group your household belongs.

O Below 500 EURO

O 500 to 1,000 EURO

O 1,000 to 1,500 EURO

O 1,500 to 2,000 EURO

O 2,000 to 3,000 EURO

O 3,000 to 4,000 EURO

O 4,000 to 5,000 EURO

O 5,000 EURO and more

O Don't know

O N/A 


\section{Appendix C: Questionnaire - Online Survey among Professional Investors ${ }^{25}$}

\section{Introduction}

We would like to ask you for your participation in our study and for five minutes of your time.

The study is about your personal attitude towards executive compensation in large German firms (DAX30). When we ask you about the total amount of compensation, we mean the sum of fixed salary, variable compensation, and the value of potential stock and option awards. For the following questions, please refer always to the CEO of an average DAX30-firm.

(For your information: In 2012, a DAX30-firm had an average net income of $€ 2.1$ billion and employed about 130,000 people.)

\section{Questions - Executive Compensation}

\section{COMP_FAIR}

Which total annual amount of compensation would you consider fair for the CEO of such a firm? Please state a $€$-amount per year.

$\mathbf{O}$ EURO

O Don't know

O N/A

\section{COMP_UNFAIR}

Irrespective of the CEO's performance, what do you think: Above which total amount can the compensation no longer be considered fair? Please state again a $€$-amount per year.

$\mathbf{O}$ EURO

O Don't know

O N/A

\footnotetext{
${ }^{25}$ The questions presented in Appendix C are taken from the original questionnaire that was used for the online survey of investment professionals. Note that participants in the online survey received questions for the same compensation-related constructs as participants in the telephone survey. Minor adjustments were made in the introduction and the questions due to analysts' deeper understanding of the topic and the fact that participants could read (and re-read) the questions on their own instead of listening to an interviewer. As this survey was also conducted in German, we translated all questions to be as close as possible to the original questions.
} 
Independent of your personal fairness preferences, what do you think: Which total amount of compensation would a particularly capable manager request at minimum for assuming the management of an average DAX30-firm? Please state a $€$-amount per year.

$\mathbf{O}$ EURO

O Don't know

O N/A

VAR_SHARE

Please assume the following situation: The CEO and his or her firm achieve all targets by exactly $100 \%$ at the end of the fiscal year. What should the structure of the realized compensation look like, i.e., which percentage of the CEO's compensation for this year should consist of variable components? Please state a percentage between 0 and 100 .

$\mathbf{O}$ $\%$

O Don't know

O N/A

FAIR_A, FAIR_B, PPS, RISK_PREM

We would like to know how important the following criteria are for you when judging the total compensation amount of CEOs.

Please indicate your agreement with the following statements.

\begin{tabular}{|c|c|c|c|c|c|c|c|c|}
\hline \multirow{2}{*}{$\begin{array}{l}\text { It is important to me... } \\
\text {...that the absolute total amount of executive } \\
\text { compensation is fair. }\end{array}$} & \multicolumn{4}{|c|}{$\begin{array}{l}\text { Fully } \\
\text { disagree }\end{array}$} & \multicolumn{4}{|c|}{$\begin{array}{l}\text { Fully } \\
\text { agree }\end{array}$} \\
\hline & 1 & 2 & 3 & 4 & 5 & 6 & 7 & N/A \\
\hline $\begin{array}{l}\text {...that the absolute total amount does not } \\
\text { exceed a threshold that I no longer consider } \\
\text { acceptable. }\end{array}$ & 1 & 2 & 3 & 4 & 5 & 6 & 7 & N/A \\
\hline $\begin{array}{l}\text {...that executive compensation is closely } \\
\text { related to changes in the firm value. }\end{array}$ & 1 & 2 & 3 & 4 & 5 & 6 & 7 & N/A \\
\hline $\begin{array}{l}\text {...that a higher executive compensation is only } \\
\text { granted when the CEO carries more risk in } \\
\text { return. }\end{array}$ & 1 & 2 & 3 & 4 & 5 & 6 & 7 & N/A \\
\hline
\end{tabular}


COMP_ACTUAL

And what do you think: How large was the actual average total amount of compensation of a $\mathrm{CEO}$ in the last year? Please state a $€$-amount per year.

$\mathbf{O}$ EURO

O Don't know

O N/A

\section{Questions - Demographics}

\section{COVERAGE}

In my job, I intensively deal with the DAX30-firms.

\begin{tabular}{|cccccccc|c|} 
Fully disagree & \multicolumn{1}{c}{} & \multicolumn{4}{c}{ Fully agree } \\
\hline 1 & 2 & 3 & 4 & 5 & 6 & 7 & N/A
\end{tabular}

PROFESSION

I am a...

$1 \bigcirc$ Financial analyst (sell-side)

$5 \bigcirc$ Investment banker

$2 \bigcirc$ Financial analyst (buy-side)

$6 \bigcirc$ Banker

$3 \bigcirc$ Fund manager

$7 \bigcirc$ Investment consultant

$4 \bigcirc$ Asset manager

$8 \bigcirc$ Other (please specify):

I am located in...

$1 \bigcirc$ Germany

$2 \bigcirc$ Other (please specify):

EXPERIENCE, AGE

Please indicate...

...your job experience.

approx. years

...your age. years 
Figure 1

Estimates of executives' actual compensation by representative eligible voters and investment professionals

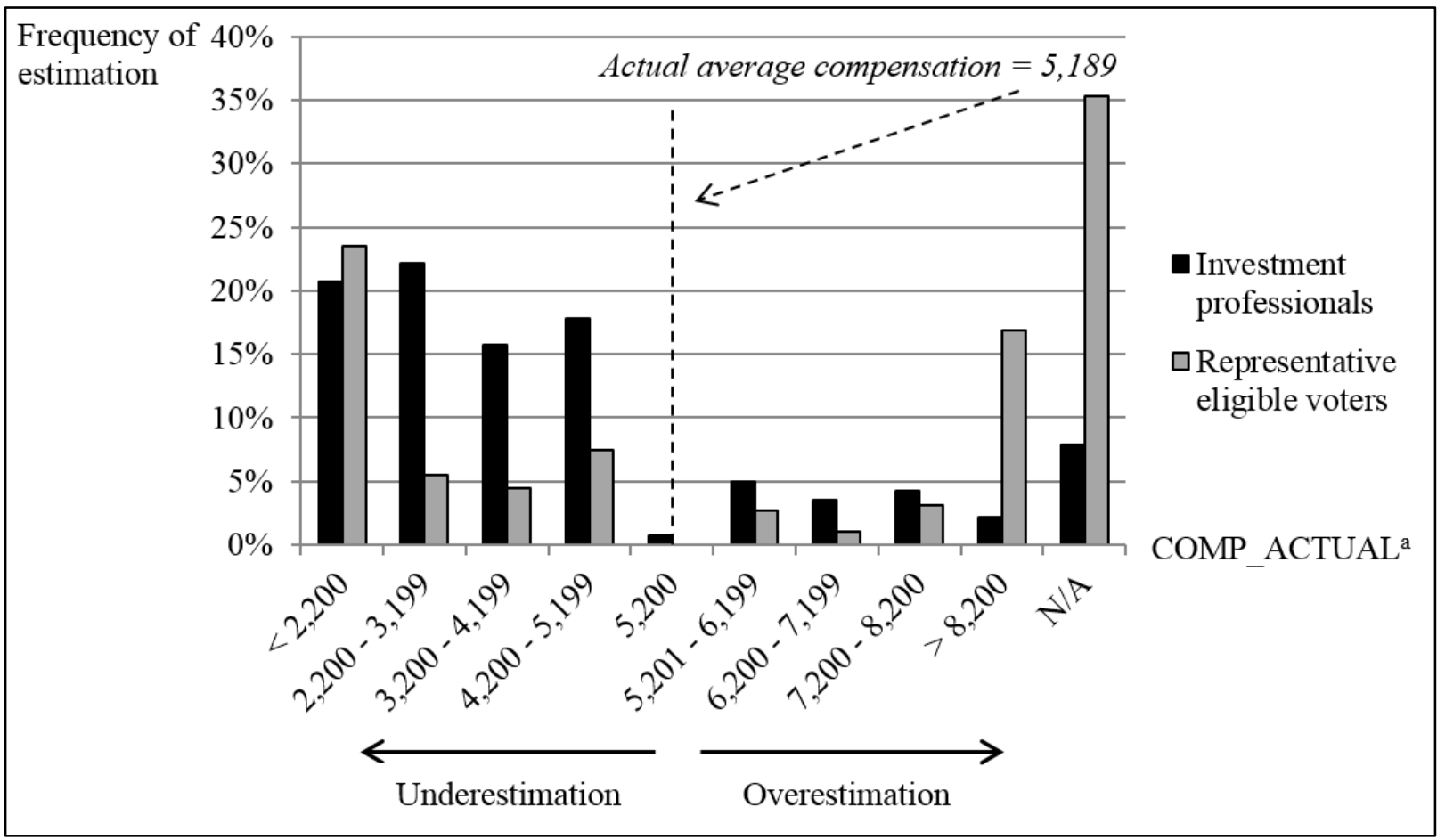

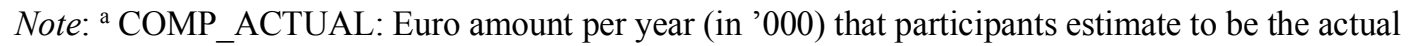
compensation of the average DAX30-CEO in 2012. 
Table 1

Descriptive statistics (representative eligible voters)

\begin{tabular}{|c|c|c|c|c|c|c|c|c|c|}
\hline \multirow[t]{2}{*}{ Variable } & \multirow[t]{2}{*}{ Mean } & \multirow[t]{2}{*}{ Std. dev. } & \multicolumn{5}{|l|}{ Percentile } & \multirow[t]{2}{*}{$N$} & \multirow[t]{2}{*}{$n / a$} \\
\hline & & & 10 th & 25 th & Median & 75 th & 90th & & \\
\hline COMP_FAIR ${ }^{\mathrm{a}}$ & $1,381,958$ & $2,242,969$ & 100,000 & 200,000 & 500,000 & $1,500,000$ & $3,500,000$ & 465 & 206 \\
\hline COMP_UNFAIR ${ }^{\mathrm{b}}$ & $4,131,144$ & $9,081,725$ & 120,000 & 400,000 & $1,000,000$ & $4,000,000$ & $10,000,000$ & 493 & 178 \\
\hline VAR_SHARE ${ }^{c}$ & $21.14 \%$ & $20.67 \%$ & $0 \%$ & $5 \%$ & $15 \%$ & $30 \%$ & $50 \%$ & 570 & 101 \\
\hline COMP_REQUEST $^{\mathrm{d}}$ & $5,070,406$ & $8,051,341$ & 200,000 & 750,000 & $2,000,000$ & $5,000,000$ & $12,000,000$ & 463 & 208 \\
\hline SIMILARITY ${ }^{\mathrm{f}}$ & 2.94 & 0.50 & 2.40 & 2.60 & 3.00 & 3.20 & 3.60 & 648 & 23 \\
\hline RISK_TOL ${ }^{\mathrm{g}}$ & 4.56 & 2.27 & 2 & 3 & 5 & 6 & 7 & 642 & 29 \\
\hline OPTIMISM $^{\mathrm{h}}$ & 3.29 & 0.64 & 3 & 3 & 3 & 4 & 4 & 646 & 25 \\
\hline COMPET $^{\mathrm{i}}$ & 2.86 & 0.62 & 2.00 & 2.50 & 3.00 & 3.00 & 3.50 & 646 & 25 \\
\hline $\mathrm{NEWS}^{\mathrm{j}}$ & 0.88 & 0.32 & 0 & 1 & 1 & 1 & 1 & 639 & 32 \\
\hline EDUCATION $^{\mathrm{k}}$ & 4.24 & 1.47 & 2 & 3 & 5 & 6 & 6 & 632 & 39 \\
\hline GENDER $^{\mathrm{m}}$ & 0.55 & 0.50 & 0 & 0 & 1 & 1 & 1 & 651 & 20 \\
\hline $\mathrm{AGE}^{\mathrm{n}}$ & 51.38 & 18.32 & 26 & 37 & 52 & 66 & 75 & 642 & 29 \\
\hline
\end{tabular}

Notes: $N$ is the number of participants who provided an answer, and $n / a$ is the number of participants who did not provide an answer.

${ }^{a}$ COMP FAIR: Euro amount per year considered fair for the representative CEO from the reference group.

${ }^{\mathrm{b}}$ COMP_UNFAIR: Euro amount per year that surpasses the participants' maximum acceptable amount beyond which any compensation would no longer be considered fair, irrespective of the CEO's performance.

c VAR SHARE: Preferred variable compensation share in executive compensation (in \%) for $100 \%$ target achievement.

${ }^{\mathrm{d}}$ COMP_REQUEST: Euro amount per year that participants assume to be the CEO's reservation wage.

${ }^{e}$ COMP_ACTUAL: Euro amount per year that participants estimate to be the actual compensation of the average DAX30-CEO in 2012.

${ }^{\mathrm{f}}$ SIMILARITY: Formative index across five questions associated with participants' perceived management skills.

g RISK_TOL: Participants' self-assessment of their risk tolerance $(1=$ not risk tolerant at all, $10=$ very risk tolerant).

${ }^{\mathrm{h}}$ OPTIMISM: Agreement with the statement "Usually, I expect that my personal affairs will turn out to be successful" $(1=$ fully disagree, $4=$ fully agree). 


\section{Table 1 (continued)}

${ }^{1}$ COMPET: Participants' agreement with the two statements "I like taking the lead in collective activities" and "I often give advice and make recommendations to others $(1$ = fully disagree, 4 = fully agree $)$.

${ }^{\mathrm{j}}$ NEWS: Participants exposure to the business news within the last three months $(0=$ no, $1=$ yes $)$.

${ }^{k}$ EDUCATION: Participants' educational attainment $(1=$ no degree, $2=$ degree after 9 years of school, $3=$ degree after 10 years of school, $4=$ high school degree after 12 years of school, $5=$ high school degree after 13 years of school, qualifying for university admission, $6=$ university degree)

${ }^{1}$ INCOME: Monthly net household income in euro $(1=0-500,2=501-1,000,3=1,001-1,500,4=1,501-2,000,5=2,001-3,000,6=3,001-4,000,7=4,001-$ $5,000,8=5,000$ and more)

m GENDER: $0=$ male, $1=$ female

n AGE: Participants' age in years. 
Table 2

Descriptive statistics (investment professionals)

\begin{tabular}{|c|c|c|c|c|c|c|c|c|c|}
\hline \multicolumn{10}{|c|}{ Panel A: Summary statistics } \\
\hline \multirow[t]{2}{*}{ Variable } & \multirow[t]{2}{*}{ Mean } & \multirow[t]{2}{*}{ Std. dev. } & \multicolumn{5}{|l|}{ Percentile } & \multirow[t]{2}{*}{$N$} & \multirow[t]{2}{*}{$n / a$} \\
\hline & & & 10 th & 25 th & Median & 75 th & 90 th & & \\
\hline COMP_FAIR ${ }^{\mathrm{a}}$ & $2,439,490$ & $2,095,191$ & 500,000 & $1,000,000$ & $2,000,000$ & $3,000,000$ & $5,000,000$ & 98 & 42 \\
\hline COMP_UNFAIR ${ }^{b}$ & $7,036,697$ & $6,466,576$ & $1,000,000$ & $3,000,000$ & $5,000,000$ & $10,000,000$ & $15,000,000$ & 109 & 31 \\
\hline VAR_SHARE ${ }^{\mathrm{c}}$ & $41.21 \%$ & $18.42 \%$ & $20 \%$ & $25 \%$ & $50 \%$ & $50 \%$ & $66 \%$ & 124 & 16 \\
\hline COMP_ACTUAL ${ }^{\mathrm{e}}$ & $3,759,302$ & $2,026,174$ & $1,250,000$ & $2,500,000$ & $3,500,000$ & $5,000,000$ & $7,000,000$ & 129 & 11 \\
\hline FAIR_A ${ }^{f}$ & 5.75 & 1.73 & 3 & 5 & 7 & 7 & 7 & 131 & 9 \\
\hline FAIR_B ${ }^{g}$ & 5.35 & 1.98 & 2 & 4 & 6 & 7 & 7 & 136 & 4 \\
\hline $\mathrm{PPS}^{\mathrm{h}}$ & 5.53 & 1.62 & 3 & 4 & 6 & 7 & 7 & 139 & 1 \\
\hline RISK_PREM ${ }^{\mathrm{i}}$ & 5.53 & 1.95 & 2 & 5 & 6 & 7 & 7 & 139 & 1 \\
\hline COVERAGE ${ }^{j}$ & 3.81 & 1.76 & 2 & 2 & 4 & 5 & 6 & 140 & 0 \\
\hline EXPERIENCE ${ }^{\mathrm{k}}$ & 19.15 & 7.12 & 10 & 15 & 20 & 25 & 30 & 140 & 0 \\
\hline $\mathrm{AGE}^{1}$ & 44.52 & 7.98 & 35 & 40 & 45 & 50 & 53 & 140 & 0 \\
\hline \multicolumn{10}{|c|}{ Panel B: Profession and country } \\
\hline \multicolumn{2}{|l|}{ Profession } & $N$ & $\%$ & \multicolumn{2}{|c|}{ Country } & $N$ & $\%$ & & \\
\hline \multicolumn{2}{|c|}{ Analyst (buy-side and sell-side) } & 25 & $17.9 \%$ & \multicolumn{2}{|c|}{ Germany } & 130 & $92.9 \%$ & & \\
\hline \multicolumn{2}{|l|}{ Fund manager } & 43 & $30.7 \%$ & \multicolumn{2}{|c|}{ Switzerland } & 8 & $5.7 \%$ & & \\
\hline \multicolumn{2}{|l|}{ Investment banker } & 23 & $16.4 \%$ & \multicolumn{2}{|c|}{ Austria } & 1 & $0.7 \%$ & & \\
\hline \multicolumn{2}{|l|}{ Banker } & 27 & $19.3 \%$ & \multicolumn{2}{|c|}{ USA } & 1 & $0.7 \%$ & & \\
\hline \multicolumn{2}{|l|}{ Investment consultant } & 8 & $5.7 \%$ & & & & & & \\
\hline \multicolumn{2}{|c|}{ Other (e.g., broker, risk manager) } & 14 & $10.0 \%$ & & & & & & \\
\hline
\end{tabular}




\section{Table 2 (continued)}

Notes: $N$ is the number of participants who provided an answer, and $n / a$ is the number of participants who did not provide an answer.

${ }^{a}$ COMP_FAIR: Euro amount per year considered fair for the representative CEO from the reference group.

${ }^{b}$ COMP_UNFAIR: Euro amount per year that surpasses the participants' maximum acceptable amount beyond which any compensation would no longer be considered fair, irrespective of the CEO's performance.

${ }^{\mathrm{c}}$ VAR_SHARE: Preferred variable compensation share in executive compensation (in \%) for $100 \%$ target achievement.

${ }^{\mathrm{d}}$ COMP_REQUEST: Euro amount per year that participants assume to be the CEO's reservation wage.

' COMP ACTUAL: Euro amount per year that participants estimate to be the actual compensation of the average DAX30-CEO in 2012.

${ }^{\mathrm{f}}$ FAIR_AA: Participants' agreement with the statement "It is important to me that the absolute total amount of executive compensation is fair" $(1=$ fully disagree, $7=$ fully agree).

g FAIR B: Participants' agreement with the statement "It is important to me that the absolute total amount does not exceed a threshold that I no longer consider acceptable" ( 1 = fully disagree, 7 = fully agree $)$.

${ }^{h}$ PPS: Participants' agreement with the statement "It is important to me that executive compensation is closely related to changes in the firm value" $(1=$ fully disagree, 7 = fully agree)

'RISK_PREM: Participants' agreement with the statement "It is important to me that a higher executive compensation is only granted when the CEO carries more risk in return" $(1=$ fully disagree, 7 = fully agree $)$.

'COVERAGE: Measures how much the participants' job includes close coverage of the DAX30-firms.

${ }^{\mathrm{k}}$ EXPERIENCE: Participants' job experience in years.

${ }^{1}$ AGE: Participants' age in years. 
Table 3

Correlation matrix (representative eligible voters)

\begin{tabular}{|c|c|c|c|c|c|c|c|c|c|c|c|c|c|}
\hline & $(1)$ & (2) & (3) & (4) & $(5)$ & (6) & (7) & $(8)$ & (9) & $(10)$ & (11) & (12) & (13) \\
\hline (1) COMP_FAIR ${ }^{\mathrm{a}}$ & 1.000 & & & & & & & & & & & & \\
\hline (2) COMP_UNFAIR ${ }^{b}$ & $0.701^{* * *}$ & 1.000 & & & & & & & & & & & \\
\hline (3) VAR_SHARE ${ }^{c}$ & $0.268^{* * *}$ & $0.189^{* * *}$ & 1.000 & & & & & & & & & & \\
\hline (4) COMP_REQUEST ${ }^{\mathrm{d}}$ & $0.414^{* * *}$ & $0.436^{* * *}$ & $0.436^{* * *}$ & 1.000 & & & & & & & & & \\
\hline (5) COMP_ACTUAL ${ }^{\mathrm{e}}$ & $0.316^{* * *}$ & $0.440^{* * *}$ & 0.011 & $0.557^{* * *}$ & 1.000 & & & & & & & & \\
\hline (6) SIMILARITY ${ }^{f}$ & $0.160^{* * *}$ & $0.101^{* *}$ & $0.124^{* * *}$ & 0.022 & $0.092^{*}$ & 1.000 & & & & & & & \\
\hline (7) RISK_TOL ${ }^{g}$ & 0.046 & $0.080^{*}$ & $0.119^{* * *}$ & -0.013 & -0.025 & $0.323^{* * *}$ & 1.000 & & & & & & \\
\hline (8) OPTIMISM $^{\mathrm{h}}$ & $0.080^{*}$ & $0.078^{*}$ & $0.078^{*}$ & 0.024 & 0.013 & $0.348^{* * *}$ & $0.195^{* * *}$ & 1.000 & & & & & \\
\hline (9) COMPET $^{\mathrm{i}}$ & $0.109^{* *}$ & $0.136^{* * *}$ & $0.093^{* *}$ & 0.015 & $0.085^{*}$ & $0.507^{* * *}$ & $0.237^{* * *}$ & $0.114^{* * *}$ & 1.000 & & & & \\
\hline (10) NEWS & $0.128^{* * *}$ & $0.113^{* *}$ & $0.071^{*}$ & $0.085^{*}$ & 0.030 & $0.138^{* * *}$ & -0.020 & 0.035 & 0.046 & 1.000 & & & \\
\hline (11) EDUCATIONk & $0.126^{* * *}$ & $0.109^{* *}$ & $0.181^{* * *}$ & $0.127^{* * *}$ & 0.053 & $0.104^{* * *}$ & $0.132^{* * *}$ & 0.056 & 0.045 & $0.097^{* *}$ & 1.000 & & \\
\hline (12) $\mathrm{INCOME}^{1}$ & $0.135^{* * *}$ & $0.121^{* *}$ & $0.152^{* * *}$ & $0.085^{*}$ & 0.012 & $0.163^{* * *}$ & $0.083^{*}$ & $0.160^{* * *}$ & -0.023 & $0.098^{* *}$ & $0.238^{* * *}$ & 1.000 & \\
\hline (13) GENDER $^{\mathrm{m}}$ & $-0.185^{* * *}$ & $-0.145^{* * *}$ & $-0.161^{* * *}$ & $-0.165^{* * *}$ & $-0.102^{* *}$ & $-0.119^{* * *}$ & $-0.145^{* * *}$ & -0.029 & $-0.084^{* *}$ & -0.012 & -0.016 & $-0.098^{* *}$ & 1.000 \\
\hline (14) $\mathrm{AGE}^{\mathrm{n}}$ & -0.032 & -0.084 & -0.041 & 0.006 & 0.071 & -0.059 & $-0.196^{* * *}$ & 0.022 & $-0.187^{* * *}$ & 0.060 & $-0.230^{* * *}$ & 0.022 & 0.052 \\
\hline
\end{tabular}

Notes: The table shows Pearson correlation coefficients. *,**, and *** represent significance levels of 10 percent, 5 percent, and 1 percent , two-tailed.

${ }^{a}$ COMP_FAIR: Euro amount per year considered fair for the representative CEO from the reference group.

b COMP UNFAIR: Euro amount per year that surpasses the participants' maximum acceptable amount beyond which any compensation would no longer be considered fair, irrespective of the CEO's performance.

${ }^{c}$ VAR_SHARE: Preferred variable compensation share in executive compensation (in \%) for 100\% target achievement.

${ }^{\mathrm{d}}$ COMP REQUEST: Euro amount per year that participants assume to be the CEO's reservation wage.

${ }^{\mathrm{e}}$ COMP ACTUAL: Euro amount per year that participants estimate to be the actual compensation of the average DAX30-CEO in 2012.

${ }^{f}$ SIMILARITY: Formative index across five questions associated with participants' perceived management skills.

' RISK TOL: Participants' self-assessment of their risk tolerance $(1=$ not risk tolerant at all, $10=$ very risk tolerant $)$

h OPTIMISM: Agreement to the statement "Usually, I expect that my personal affairs will turn out to be successful" ( $1=$ fully disagree, $4=$ fully agree).

i COMPET: Participants" agreement to the two statements "I like taking the lead in collective activities" and "I often give advice and make recommendations to others ( 1 = fully disagree, 4 = fully agree).

${ }^{\mathrm{j}}$ NEWS: Participants exposure to the business news within the last three months $(0=$ no, $1=$ yes $)$. 


\section{Table 3 (continued)}

${ }^{k}$ EDUCATION: Participants' educational attainment $(1=$ no degree, $2=$ degree after 9 years of school, $3=$ degree after 10 years of school, $4=$ high school degree after 12 years, $5=$ high school degree after 13 years, qualifying for university admission, $6=$ university degree).

${ }^{1}$ INCOME: Monthly net household income in euro $(1=0-500,2=501-1,000,3=1,001-1,500,4=1,501-2,000,5=2,001-3,000,6=3,001-4,000,7=4,001-5,000,8=$ 5,000 and more).

${ }^{\mathrm{m}}$ GENDER: $0=$ male, $1=$ female .

' AGE: Participants' age in years. 
Table 4

Determinants of opinions on fairness of executive compensation amounts (eligible voters)

\begin{tabular}{|c|c|c|c|c|c|}
\hline & Hypothesis & $\begin{array}{l}\text { COMP } \\
\text { FAIR }^{\mathrm{a}} \\
(1)\end{array}$ & $\begin{array}{c}\text { COMP_- } \\
\text { FAIR } \\
\text { (2) }\end{array}$ & $\begin{array}{l}\text { COMP } \\
\text { UNFAIR }^{\mathrm{b}} \\
\text { (3) }\end{array}$ & $\begin{array}{l}\text { COMP } \\
\text { UNFAIR } \\
(4)\end{array}$ \\
\hline SIMILARITY $^{c}$ & $\mathrm{H} 2[+]$ & $\begin{array}{c}568,897 \\
(214,440)^{* * *}\end{array}$ & $\begin{array}{c}513,673 \\
(251,055)^{* *}\end{array}$ & $\begin{array}{c}1,670,155 \\
(904,519)^{* *}\end{array}$ & $\begin{array}{c}1,419,136 \\
(1,041,727)^{*}\end{array}$ \\
\hline VAR_SHARE $^{\mathrm{d}}$ & $\mathrm{H} 3[+]$ & $\begin{array}{c}27,908 \\
(6,907)^{* * *}\end{array}$ & $\begin{array}{c}27,210 \\
(7,269)^{* * *}\end{array}$ & $\begin{array}{c}80,365 \\
(27,776)^{* * *}\end{array}$ & $\begin{array}{c}72,419 \\
(23,106)^{* * *}\end{array}$ \\
\hline NEWS $^{\mathrm{e}}$ & & & $\begin{array}{c}663,346 \\
(225,111)^{* * *}\end{array}$ & & $\begin{array}{c}2,479,054 \\
(1,547,567)\end{array}$ \\
\hline EDUCATION $^{f}$ & & & $\begin{array}{c}76,877 \\
(85,049)\end{array}$ & & $\begin{array}{c}64,095 \\
(349,731)\end{array}$ \\
\hline $\mathrm{INCOME}^{\mathrm{g}}$ & & & $\begin{array}{c}30,591 \\
(67,144)\end{array}$ & & $\begin{array}{c}262,061 \\
(259,193)\end{array}$ \\
\hline GENDER $^{\mathrm{h}}$ & & & $\begin{array}{c}-687,285 \\
(216,705)^{* * *}\end{array}$ & & $\begin{array}{c}-1,896,865 \\
(942,370)^{* *}\end{array}$ \\
\hline $\mathrm{AGE}^{\mathrm{i}}$ & & & $\begin{array}{c}825 \\
(7,070)\end{array}$ & & $\begin{array}{l}-44,189 \\
(28,932)\end{array}$ \\
\hline Const. & & $\begin{array}{l}-886,938 \\
(609,382)\end{array}$ & $\begin{array}{c}-1,422,991 \\
(883,581)\end{array}$ & $\begin{array}{l}-2,513,432 \\
(2,703,585)\end{array}$ & $\begin{array}{l}-2,011,556 \\
(3,732,303)\end{array}$ \\
\hline$R^{2}$ & & 0.09 & 0.13 & 0.04 & 0.08 \\
\hline$N$ & & 449 & 386 & 474 & 401 \\
\hline
\end{tabular}

Notes: The table reports OLS-regressions with robust standard errors for the eligible voters sample on the fair compensation amount (COMP_FAIR) and the maximum acceptable amount (COMP_UNFAIR). *,**, and *** represent significance levels of 10 percent, 5 percent, and 1 percent, respectively. p-values are one-tailed for variables with a directional hypothesis $(+,-)$ and two-tailed otherwise (standard errors shown in parentheses). ${ }^{a}$ COMP_FAIR: Euro amount per year considered fair for the representative CEO from the reference group.

${ }^{\mathrm{b}}$ COMP_UNFAIR: Euro amount per year that surpasses the participants' maximum acceptable amount beyond which any compensation would no longer be considered fair, irrespective of the CEO's performance.

' SIMILARITY: Formative index across five questions associated with participants' perceived management skills.

${ }^{\mathrm{d}}$ VAR_SHARE: Preferred variable compensation share in executive compensation (in \%) for $100 \%$ target achievement.

e NEWS: Participants' exposure to business news within the last three months $(0=$ no, $1=$ yes $)$.

${ }^{\mathrm{f}}$ EDUCATION: Participants' educational attainment $(1=$ no degree, $2=$ degree after 9 years of school, $3=$ degree after 10 years of school, $4=$ high school degree after 12 years, $5=$ high school degree after 13 years, qualifying for university admission, 6 = university degree).

g INCOME: Monthly net household income in euro $(1=0-500,2=501-1,000,3=1,001-1,500,4=1,501-2,000$, $5=2,001-3,000,6=3,001-4,000,7=4,001-5,000,8=5,000$ and more).

${ }^{\mathrm{h}}$ GENDER: $0=$ male, 1 = female.

'AGE: Participants' age in years. 
Table 5

Determinants of opinions on fairness of executive compensation amounts (investment professionals)

\begin{tabular}{|c|c|c|c|c|}
\hline & $\begin{array}{c}\text { COMP } \\
\text { FAIR }^{\mathrm{a}} \\
(1)\end{array}$ & $\begin{array}{c}\mathrm{COMP}_{-} \\
\text {FAIR } \\
(2)\end{array}$ & $\begin{array}{c}\text { COMP } \\
\text { UNFAIR }^{\mathrm{b}} \\
(3)\end{array}$ & $\begin{array}{c}\text { COMP } \\
\text { UNFAIR } \\
(4)\end{array}$ \\
\hline \multirow[t]{2}{*}{ VAR_SHARE ${ }^{c}$} & 27,104 & 37,064 & 95,355 & 92,851 \\
\hline & $(9,887)^{* * *}$ & $(12,550)^{* * *}$ & $(40,767)^{* *}$ & $(45,277)^{* *}$ \\
\hline \multirow[t]{2}{*}{ COVERAGE $^{\mathrm{d}}$} & & $-33,745$ & & $-9,011$ \\
\hline & & $(143,415)$ & & $(329,463)$ \\
\hline \multirow[t]{2}{*}{ EXPERIENCE $^{\mathrm{e}}$} & & 89,725 & & $-37,360$ \\
\hline & & $(52,020)^{*}$ & & $(195,934)$ \\
\hline \multirow[t]{2}{*}{$\mathrm{AGE}^{\mathrm{f}}$} & & $-42,680$ & & $-120,870$ \\
\hline & & $(44,639)$ & & $(187,148)$ \\
\hline \multirow[t]{2}{*}{ prof_analyst ${ }^{\mathrm{g}}$} & & $2,339,093$ & & $1,807,243$ \\
\hline & & $(1,066,015)^{* *}$ & & $(1,766,121)$ \\
\hline \multirow[t]{2}{*}{ prof_fund_manager ${ }^{\mathrm{g}}$} & & 333,390 & & $1,739,977$ \\
\hline & & $(672,040)$ & & $(1,857,337)$ \\
\hline \multirow[t]{2}{*}{ prof_investment_banker ${ }^{\mathrm{g}}$} & & 599,252 & & 860,979 \\
\hline & & $(621,406)$ & & $(1,645,339)$ \\
\hline \multirow{2}{*}{ prof_banker ${ }^{\mathrm{g}}$} & & $-53,132$ & & $-566,887$ \\
\hline & & $(633,769)$ & & $(1,693,768)$ \\
\hline \multirow[t]{2}{*}{ prof_investment_consultant ${ }^{\mathrm{g}}$} & & $-704,902$ & & $4,192,726$ \\
\hline & & $(718,723)$ & & $(3,977,303)$ \\
\hline \multirow[t]{2}{*}{ Const. } & $1,389,982$ & 671,481 & $3,339,483$ & $8,568,910$ \\
\hline & $(357,878)^{* * *}$ & $(1,751,435)$ & $(1,517,705)^{* *}$ & $(4,988,218)^{*}$ \\
\hline$R^{2}$ & 0.06 & 0.21 & 0.07 & 0.13 \\
\hline$N$ & 94 & 94 & 103 & 103 \\
\hline
\end{tabular}

Notes: The table reports OLS-regressions with robust standard errors for the investment professionals sample on the fair compensation amount (COMP_FAIR) and the maximum acceptable amount (COMP_UNFAIR). *,**, and *** represent significance levels of 10 percent, 5 percent, and 1 percent, respectively. p-values are twotailed (standard errors shown in parentheses).

${ }^{\text {a }}$ COMP_FAIR: Euro amount per year considered fair for the representative CEO from the reference group.

' COMP_UNFAIR: Euro amount per year that surpasses the participants' maximum acceptable amount beyond which any compensation would no longer be considered fair, irrespective of the CEO's performance.

' VAR_SHARE: Preferred variable target compensation share executive compensation (in \%).

${ }^{d}$ COVERAGE: Measures how much the participants' job includes close coverage of the DAX30-firms.

'EXPERIENCE: Participants' job experience in years.

${ }^{\mathrm{f}}$ AGE: Participants' age in years.

g Dummy variables for the participants' professions as displayed in Table 2, Panel B. Buy-side and sell-side analysts are combined as "prof_analyst", and "other" professions represent the baseline group for this analysis. 
Table 6

Determinants of the preferred executive compensation risk

(eligible voters)

\begin{tabular}{|c|c|c|c|c|}
\hline & Hypothesis & $\begin{array}{c}\text { VAR_SHARE }^{\mathrm{a}} \\
(1)\end{array}$ & $\begin{array}{c}\text { VAR_SHARE } \\
(2) \\
\end{array}$ & $\begin{array}{c}\text { VAR_SHARE } \\
\text { (3) } \\
\end{array}$ \\
\hline \multirow[t]{2}{*}{ RISK_TOL $^{b}$} & $\mathrm{H} 4 \mathrm{a}[+]$ & 0.90 & 0.91 & 0.67 \\
\hline & & $(0.39)^{* *}$ & $(0.39)^{* *}$ & $(0.44)^{*}$ \\
\hline \multirow[t]{2}{*}{ [A] OPTIMISM ${ }^{\mathrm{c}}$} & $\mathrm{H} 4 \mathrm{~b}[+]$ & 1.70 & 2.06 & 2.29 \\
\hline & & $(1.30)^{*}$ & $(1.34)^{*}$ & $(1.46)^{*}$ \\
\hline \multirow{2}{*}{ [B] $\mathrm{COMPET}^{\mathrm{d}}$} & $\mathrm{H} 4 \mathrm{c}[+]$ & 2.36 & 1.95 & 2.60 \\
\hline & & $(1.38)^{* *}$ & $(1.34)^{*}$ & $(1.43)^{* *}$ \\
\hline \multirow[t]{2}{*}[\mathrm{A}]{$\mathrm{x}[\mathrm{B}]$ Interaction } & $\mathrm{H} 4 \mathrm{~d}[+]$ & & 4.54 & 4.62 \\
\hline & & & $(1.84)^{* * *}$ & $(1.91)^{* * *}$ \\
\hline \multirow[t]{2}{*}{$\mathrm{NEWS}^{\mathrm{e}}$} & & & & 4.02 \\
\hline & & & & $(2.72)$ \\
\hline \multirow[t]{2}{*}{ EDUCATION $^{\mathrm{f}}$} & & & & 1.74 \\
\hline & & & & $(0.70)^{* *}$ \\
\hline \multirow[t]{2}{*}{$\mathrm{INCOME}^{\mathrm{g}}$} & & & & 0.81 \\
\hline & & & & $(0.50)$ \\
\hline \multirow[t]{2}{*}{ GENDER $^{\mathrm{h}}$} & & & & -5.92 \\
\hline & & & & $(1.88)^{* * *}$ \\
\hline \multirow[t]{2}{*}{$\mathrm{AGE}^{\mathrm{i}}$} & & & & 0.02 \\
\hline & & & & $(0.05)$ \\
\hline \multirow[t]{2}{*}{ Const. } & & 4.64 & 47.17 & 33.77 \\
\hline & & $(5.68)$ & $(16.74)^{* * *}$ & $(18.29)^{*}$ \\
\hline$R^{2}$ & & 0.02 & 0.03 & 0.10 \\
\hline$N$ & & 563 & 563 & 475 \\
\hline
\end{tabular}

Notes: The table reports OLS-regressions with robust standard errors for the eligible voters sample on the preferred variable target compensation share (VAR_SHARE). Coefficients for OPTIMISM and COMPET in Model (2) and (3) reflect effects with mean centering of the respective other variable. *, ${ }^{* *}$, and *** represent significance levels of 10 percent, 5 percent, and 1 percent, respectively. $p$-values are one-tailed for variables with a directional hypothesis $(+,-)$ and two-tailed otherwise (standard errors shown in parentheses).

${ }^{\text {a }}$ VAR_SHARE: Preferred variable target compensation share in executive compensation (in \%).

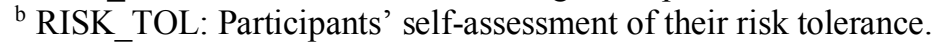

' OPTIMISM: Agreement with "Usually, I expect that my personal affairs will turn out to be successful".

${ }^{d}$ COMPET: Participants' agreement with the two statements "I like taking the lead in collective activities" and "I often give advice and make recommendations to others".

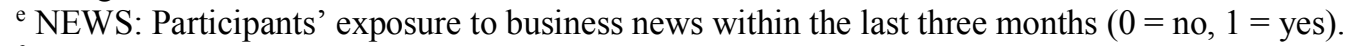

${ }^{\mathrm{f}}$ EDUCATION: Participants' educational attainment $(1=$ no degree, $2=$ degree after 9 years of school, $3=$ degree after 10 years of school, $4=$ high school degree after 12 years, $5=$ high school degree after 13 years, qualifying for university admission, 6 = university degree).

g INCOME: Monthly net household income in euro $(1=0-500,2=501-1,000,3=1,001-1,500,4=1,501-2,000$, $5=2,001-3,000,6=3,001-4,000,7=4,001-5,000,8=5,000$ and more $)$.

${ }^{\mathrm{h}}$ GENDER: $0=$ male, $1=$ female.

${ }^{\text {i }}$ AGE: Participants' age in years. 